\title{
Amyloidoza łańcuchów lekkich immunoglobulin z punktu widzenia kardiologa
}

\section{Light chain cardiac amyloidosis from the cardiologists' point of view}

\author{
Jacek Grzybowski ${ }^{1}$, Justyna Szczygieł ${ }^{1}$, Monika Gawor ${ }^{1}$, Piotr Michałek ${ }^{2}$, Agnieszka Sioma ${ }^{1}$, \\ Natalia Ojrzyńska ${ }^{1}$, Łukasz Mazurkiewicz ${ }^{1,3}$, Marta Legatowicz-Koprowska ${ }^{4}$, Ewa Walczak ${ }^{4}$, \\ Maria Franaszczyk ${ }^{5}$, Magdalena Marczak ${ }^{3}$ \\ ${ }^{1}$ Oddział Kardiomiopatii, Instytut Kardiologii, Warszawa \\ ${ }^{2}$ Izba Przyjęć i Oddział Szybkiej Diagnostyki, Instytut Kardiologii, Warszawa \\ ${ }^{3}$ Pracownia Rezonansu Magnetycznego, Instytut Kardiologii, Warszawa \\ ${ }^{4}$ Zakład Patomorfologii, Narodowy Instytut Geriatrii, Reumatologii i Rehabilitacji, Warszawa \\ ${ }^{5}$ Zakład Biologii Medycznej, Pracownia Biologii Molekularnej, Instytut Kardiologii, Warszawa
}

\begin{abstract}
Streszczenie
Amyloidoze tańcuchów lekkich (amyloidoze AL) rozpoznaje się u okoto $70 \%$ pacjentów z amyloidoza serca. Ta postać choroby wiaże sie z najgorszym rokowaniem, szczególnie jeśli wykrywa sie ja na zaawansowanym etapie. Kardiolog jest najcześsciej odwiedzanym specjalista przez pacjentów $z$ amyloidozq $A L$. Niestety tylko u co piatego pacjenta jest stawiana wtaściwa diagnoza. Dlatego ważne jest, aby promować dziatania umożliwiajace wczesne stwierdzenie choroby. Należy do nich oznaczanie wolnych tańcuchów lekkich (FLC) $w$ surowicy u pacjentów $z$ niewydolnościq serca z zachowana frakcja wyrzutowa. Wykazanie kardiotoksycznej roli FLC zmienito postrzeganie amyloidozy AL jako choroby polegajacej wytacznie na pozakomórkowym gromadzeniu sie nieprawidtowych złogów biatkowych. Największa poprawe funkcji serca uzyskuje się, obnizajac stężnie FLC $w$ surowicy poprzez leczenie cytoredukcyjne. Leczenie kardiologiczne ma znaczenie uzupetniajace. Rola kardiologa sprowadza sie do jak najszybszego rozpoznania choroby i przekazania pacjenta do hematologa. Standardowa farmakoterapia niewydolności serca, obejmujaca beta-adrenolityki $i$ inhibitory konwertazy angiotensyny, $u$ pacjentów $z$ amyloidoza wywotuje nasilenie hipotensji ortostatycznej i objawów zastoinowych. Natomiast dzięki nowoczesnemu leczeniu cytoredukcyjnemu $i$ antyamyloidowemu istotnie poprawity sie wyniki leczenia, pod warunkiem wczesnego rozpoznania amyloidozy $A L$.
\end{abstract}

Słowa kluczowe: amyloidoza łańcuchów lekkich, amyloidoza AL, amyloidoza serca, niewydolność serca z zachowaną frakcją wyrzutową

Hematologia 2018; 9, 3: 222-238

\section{Abstract}

Light-chain amyloidosis (amyloidosis $A L$ ) is diagnosed in approx. $70 \%$ of patients with cardiac amyloidosis. This type of amyloidosis has the worst prognosis, especially if the diagnosis is made in advanced stages. The majority of patients are referred to a cardiologist, but unfortunately only

Adres do korespondencji: Jacek Grzybowski, Oddział Kardiomiopatii, Instytut Kardiologii, ul. Alpejska 42, 04-628 Warszawa, tel. 223434 671, faks 223434 515, e-mail: jgrzybowski@ikard.pl 
every fifth of them has the proper diagnosis. Therefore, strategies promoting early diagnosis are important. One of them is the measurement of serum free light chains (FLC) concentration in every patient with heart failure with preserved ejection fraction. The acknowledgement of FLC cardiotoxicity rendered the picture of AL amyloidosis from infiltrative cardiomyopathy into a toxic one. Best improvement in regard to heart failure is achieved upon cytoreduction resulting in decrease of FLC concentration. Therefore, cardiological treatment is rather a supportive therapy. The role of cardiologist is the rapid diagnosis of the disease and referral of the patient to the hematologist. The standard heart failure treatment encompassing use of beta-blockers and angiotensin converting enzyme inhibitors aggravates orthostatic hypotension and congestion. Instead, up-to-date cytoreduction and antiamyloid treatment improves the prognosis markedly, as long as early diagnosis of amyloidosis is made.

\section{Key words: light-chain amyloidosis, amyloidosis AL, cardiac amyloidosis, heart failure with preserved ejection fraction}

Hematologia 2018; 9, 3: 222-238

\section{Wprowadzenie}

Niniejsze opracowanie w głównej mierze dotyczy najczęstszej i najgorzej rokującej amyloidozy łańcuchów lekkich. Jednak, zważywszy na fakt, że ustalenie typu amyloidu ma kluczowe znaczenie dla wyboru metody leczenia przyczynowego, a postępowanie kardiologiczne różni się niekiedy zależnie od rodzaju amyloidozy, na końcu każdej części omówiono odmienności związane $z$ amyloidozą transtyretynową (ATTR).

Amyloidoza serca to u około $70 \%$ pacjentów amyloidoza łańcuchów lekkich immunoglobulin (amyloidoza AL) [1]. Serce jest głównym narządem zajętym w amyloidozie ATTR typu dzikiego, tak zwanej wild-type (ATTRwt), rozpoznawanej u około $3 \%$ pacjentów $z$ amyloidozą serca zgłaszających się do centrów referencyjnych [1]. Natomiast amyloidoza ATTR spowodowana występowaniem zmutowanej formy transtyretyny (ATTRm) jest wykrywana u około 6\% pacjentów. Zależnie od typu mutacji leżącej u podłoża choroby obserwuje się całe spektrum obrazu klinicznego - od postaci wyłącznie neuropatycznej, poprzez postaci mieszane, w których pojawiają się objawy zarówno neurologiczne, jak i kardiologiczne, po postaci, w których niewydolność serca (HF, heart failure) wysuwa się na pierwszy plan, jak w mutacjach V122I, L111M czy w mutacji $V 30 M$, jeśli występuje ona w formie późno ujawniającej się (tzw. late-onset V30M) [2].

Zajęcie serca występuje u około $80 \%$ pacjentów $z$ amyloidozą AL i znacząco pogarsza rokowanie [3]. Mediana przeżycia pacjentów $z$ zastoinową HF w przebiegu amyloidozy AL wynosi 3-6 miesięcy $[4,5]$. Dzięki nowym możliwościom terapeutycznym poprawiły się wyniki leczenia amyloidozy AL [6]. Jednak nawet w krajach, w których działają centra referencyjne zajmujące się diagnostyką i leczeniem amyloidozy, $20 \%$ pacjentów umiera w krótkim czasie od rozpoznania choroby [7]. Są to pacjenci, u których diagnoza stawiana jest zbyt późno. Kardiolog to specjalista, do którego najczęściej zgłaszają się pacjenci $z$ amyloidozą AL. Niestety tylko u $20 \%$ choroba zostaje prawidłowo rozpoznana [8].

$\mathrm{W}$ amyloidozie ATTR rokowanie jest lepsze. Pacjenci przeżywają zazwyczaj 10-15 lat od początku objawów niezwiązanych $z$ układem krążenia, choć jakość życia może być istotnie obniżona [2]. Stopień uszkodzenia serca, podobnie jak w amyloidozie AL, jest głównym czynnikiem determinującym długość życia. Mediana przeżycia wynosi około 25 miesięcy od momentu wystąpienia objawowej HF w amyloidozie ATTRm i 41 miesięcy w amyloidozie ATTRwt [2].

\section{Rozpoznanie}

\section{Dane $\mathrm{z}$ wywiadu}

Najczęściej zgłaszanym, ale niespecyficznym objawem amyloidozy AL serca pozostaje narastająca duszność wysiłkowa (ryc. 1) [9]. Pacjenci często skarżą się również na wysiłkowe bóle w klatce piersiowej lub w nadbrzuszu. Objawy te częściowo wynikają $z$ niedostatecznego rzutu serca $\mathrm{w}$ czasie wysiłku, ale mogą też być spowodowane dysfunkcją mikrokrążenia w obecności wolnych łańcuchów lekkich (FLC, free light chains) [10]. Napadowa duszność nocna, czy duszność typu orthopnoe są obecne na zaawansowanym etapie choroby. U większości chorych występują wówczas również obrzęki kończyn dolnych [11]. Często występują objawy hipotensji ortostatycznej. Nierzadko pacjenci zgłaszają całkowity brak apetytu i istotne zmniejszenie 


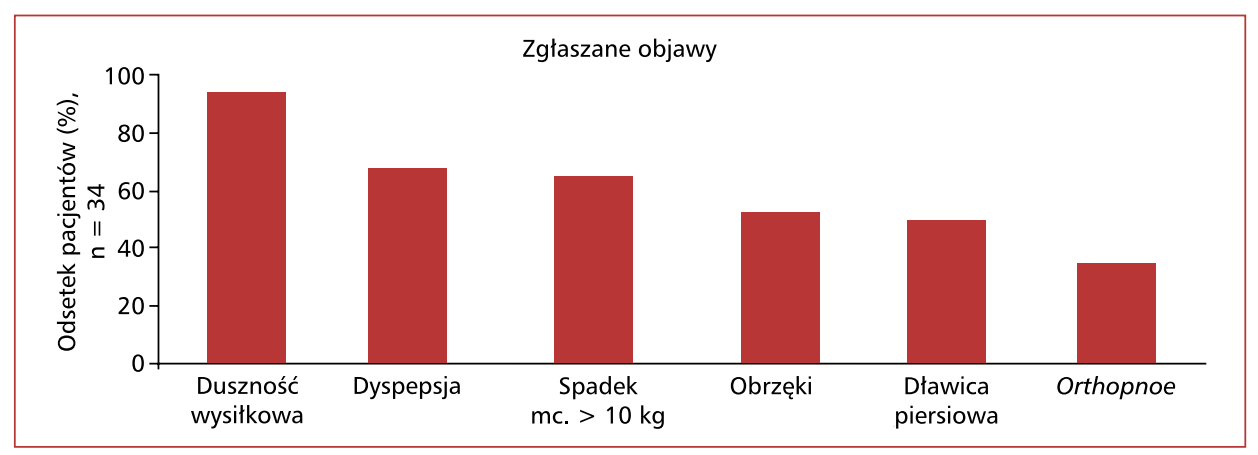

Rycina 1. Częstość występowania poszczególnych objawów zgłaszanych przez pacjentów z amyloidozą AL hospitalizowanych na Oddziale Kardiomiopatii Instytutu Kardiologii w latach 2011-2017 (opracowanie: Szczygieł J., Praca statutowa IK nr 2.48/VII/15); mc. - masa ciała

Figure 1. Frequency of symptoms reported by patients with $A L$ amyloidosis who were diagnosed in Department of Cardiomyopathy, Institute of Cardiology between 2011 and 2017 (prepared by Szczygiel J, Institute of Cardiology Grant No. 2.48/VII/15); mc. — body mass

masy ciała. Dość charakterystycznym objawem amyloidozy AL jest wstręt do potraw mięsnych, powszechnie wiązany $z$ rakiem żołądka. Opóźnione opróżnianie się żołądka wynika $z$ zajęcia autonomicznego układu nerwowego w przebiegu amyloidozy AL i powoduje uczucie wczesnej sytości po positku lub dyskomfort w nadbrzuszu. W badaniach endoskopowych u pacjentów $z$ amyloidozą AL zgłaszających objawy dyspeptyczne często stwierdza się przekrwienie błony śluzowej żołądka lub nadżerki [12]. Zastój krwi w obrębie narządów jamy brzusznej w przebiegu prawokomorowej HF powoduje dolegliwości bólowe, szczególnie w okolicy wątroby. Niekiedy pacjenci skarżą się na uporczywe biegunki lub zmienny rytm wypróżnien. Mężczyźni doświadczają zaburzeń funkcji płciowych. U około $15 \%$ pacjentów występują zaburzenia czucia w obrębie kończyn dolnych pod postacią drętwienia, mrowienia, palących lub kłujących bólów, następnie pojawia się osłabienie siły mięśniowej. Objawy te są spowodowane symetryczną, obwodową neuropatią czuciowo-ruchową [13].

W amyloidozie ATTR częściej niż w amyloidozie AL występuje zespół cieśni nadgarstka, wyprzedzający o wiele lat inne objawy choroby. Pacjenci mogą również doświadczać dolegliwości wynikających ze zwężenia kanału kręgowego. Nierzadko może się pojawić krwiomocz spowodowany odkładaniem się amyloidu w obrębie pęcherza moczowego. Znaczne zmniejszenie masy ciała najczęściej wynika $z$ zajęcia układu nerwowego przewodu pokarmowego powodującego uporczywe biegunki [2].

\section{Badanie przedmiotowe}

Przede wszystkim uwagę zwraca niedobór masy ciała, rzadziej wyniszczenie. Objawy wynikające $z$ odkładania się złogów amyloidu w tkankach miękkich, takie jak: wybroczyny w obrębie oczodołów, powiększenie języka $z$ widocznymi odciskami zębów na języku, zwiększona objętość struktur w okolicy podżuchwowej, są patognomoniczne dla amyloidozy AL, ale występują nie częściej niż u około $15 \%$ pacjentów i dopiero na zaawansowanym etapie choroby [3]. Zmiana barwy głosu i brzmienia mowy prawdopodobnie wynika głównie $z$ odkładania się złogów amyloidu w obrębie krtani [14]. Pewien udział w dysfonii może mieć również powiększenie się lewego przedsionka. Jednak przedsionki w amyloidozie, mimo że ulegają istotnemu powiększeniu, osiągają mniejsze rozmiary niż $\mathrm{w}$ innych postaciach kardiomiopatii o fizjologii restrykcyjnej [15].

Przyspieszona bądź niemiarowa czynność serca sugeruje migotanie przedsionków (AF, atrial fibrillation), które występuje u około $20 \%$ pacjentów $z$ amyloidozą AL [16]. W IV międzyżebrzu wzdłuż lewego brzegu mostka często jest słyszalny wczesnorozkurczowy III ton serca wynikający $z$ upośledzonej podatności prawej komory. Czwartego tonu serca, powstającego w mechanizmie uderzenia krwi wyrzuconej podczas skurczu przedsionków o mało podatne ściany komór, nie stwierdza się w amyloidozie ze względu na obniżoną funkcję skurczową przedsionków. W zaawansowanym stadium amyloidozy występuje holosystoliczny 


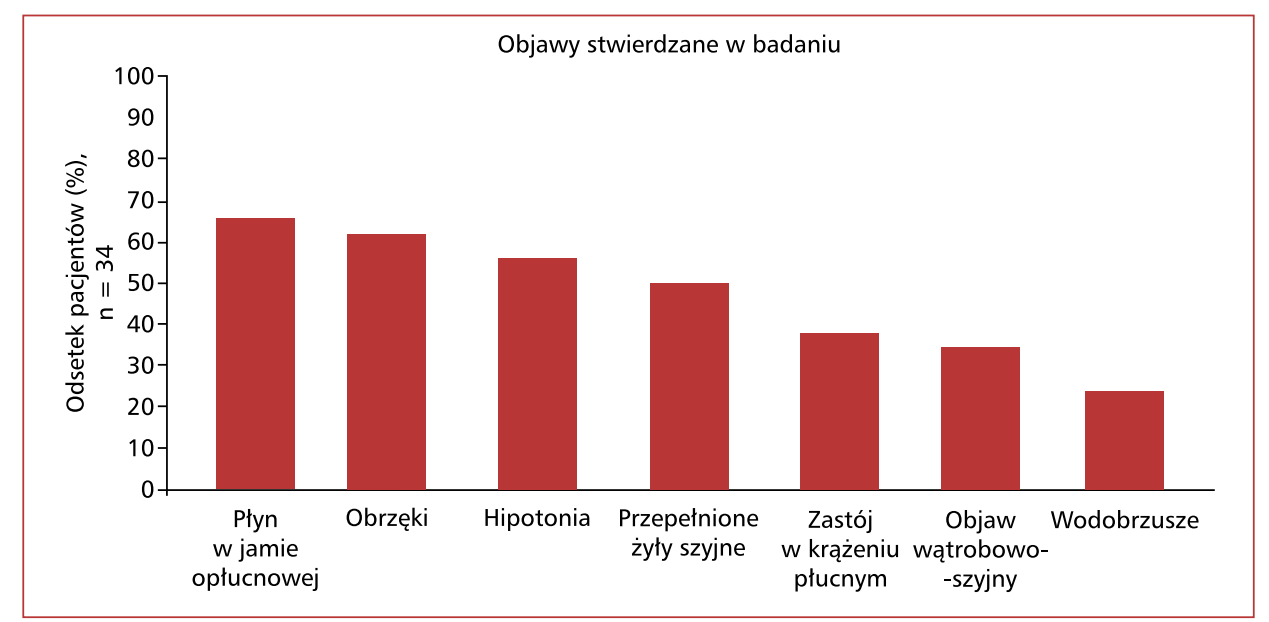

Rycina 2. Częstość występowania poszczególnych objawów w badaniu przedmiotowym pacjentów z amyloidozą $A L$ hospitalizowanych na Oddziale Kardiomiopatii Instytutu Kardiologii w latach 2011-2017 (opracowanie: Szczygieł J., Praca statutowa IK nr 2.48/VII/15)

Figure 2. Frequency of symptoms reported by patients with $A L$ amyloidosis who were diagnosed in Department of Cardiomyopathy, Institute of Cardiology between 2011 and 2017 (prepared by Szczygiel J, Institute of Cardiology Grant No. 2.48/VII/15)

szmer skurczowy najlepiej słyszalny wzdłuż dolnej części lewej krawędzi mostka - szmer niedomykalności zastawki trójdzielnej. Zwiększa on swą głośność w czasie wdechu. Ciśnienie tętnicze $u$ pacjenta $z$ amyloidozą serca jest zazwyczaj niskie. Pomiar ciśnienia tętniczego również po 1 minucie i po 3 minutach pozostawania przez pacjenta $\mathrm{w}$ pozycji stojącej umożliwia wykrycie hipotensji ortostatycznej. W badaniu przedmiotowym klatki piersiowej należy zwracać uwagę na objawy sugerujące obecność płynu w jamie opłucnowej. Ta obecność płynu wynika głównie $z$ odkładania się złogów amyloidu w obrębie opłucnej; jest to stan oporny na leczenie diuretyczne i szybko nawraca po torakocentezie [17]. Objawy osłuchowe zastoju w krążeniu płucnym stwierdza się rzadko i na zaawansowanym etapie choroby. Ze względu na częstą w amyloidozie niewydolność prawej komory powszechnie zauważanym objawem jest poszerzenie żył szyjnych. Niekiedy stwierdza się tak zwane paradoksalne tętno żylne, czyli wypełnianie się żył szyjnych podczas wdechu (objaw Kussmaula charakterystyczny dla zaciskającego zapalenia osierdzia) [9]. Na wczesnym etapie zajęcia serca dyskretnie wyrażony dodatni objaw wątrobowo-szyjny może być jedyną nieprawidłowością w badaniu przedmiotowym pacjenta $z$ amyloidozą AL. W zaawansowanej prawokomorowej HF obecne są hepatomegalia i wodobrzusze. Wątroba zastoinowa cechuje się dość dużą spoistością i może być tkliwa, odróżnia się jednak od twardej jak kamień, bardzo powiększonej i niebolesnej wątroby nacieczonej przez złogi amyloidu [16]. Należy ocenić obrzęki obwodowe. Jeśli natomiast u pacjenta $z$ uogólnionymi obrzękami nie stwierdza się poszerzonych żył szyjnych, to można podejrzewać, że przyczyną obrzęków jest hipoalbuminemia [9]. Na rycinie 2 przedstawiono częstość poszczególnych objawów stwierdzanych $\mathrm{w}$ badaniu przedmiotowym $\mathrm{u}$ pacjentów, u których rozpoznano amyloidozę AL jako przyczynę HF.

W amyloidozie ATTR, mimo większego niż $\mathrm{w}$ amyloidozie AL pogrubienia mięśnia lewej komory, zazwyczaj stan ogólny chorego jest lepszy [2]. Na plan pierwszy mogą się wysuwać objawy spowodowane zaburzeniami przewodzenia przedsionkowo-komorowego czy AF, które występuje istotnie częściej.

\section{Definicja amyloidozy AL $\mathrm{z}$ zajęciem serca}

By rozpoznać amyloidozę AL, konieczne jest wykazanie obecności złogów amyloidu $z$ łańcuchów lekkich immunoglobulin w biopsji narządowej (niekoniecznie serca) oraz wykrycie dyskrazji plazmocytów, czyli wykrycie: białka monoklonalnego metodą immunofiksacji białek surowicy bądź w dobowej zbiórce moczu, nieprawidłowego stosunku stężeń FLC kappa i FLC lambda w surowicy lub klonalnych plazmocytów w szpiku kostnym [18]. Zajęcie serca w przebiegu amyloidozy AL 


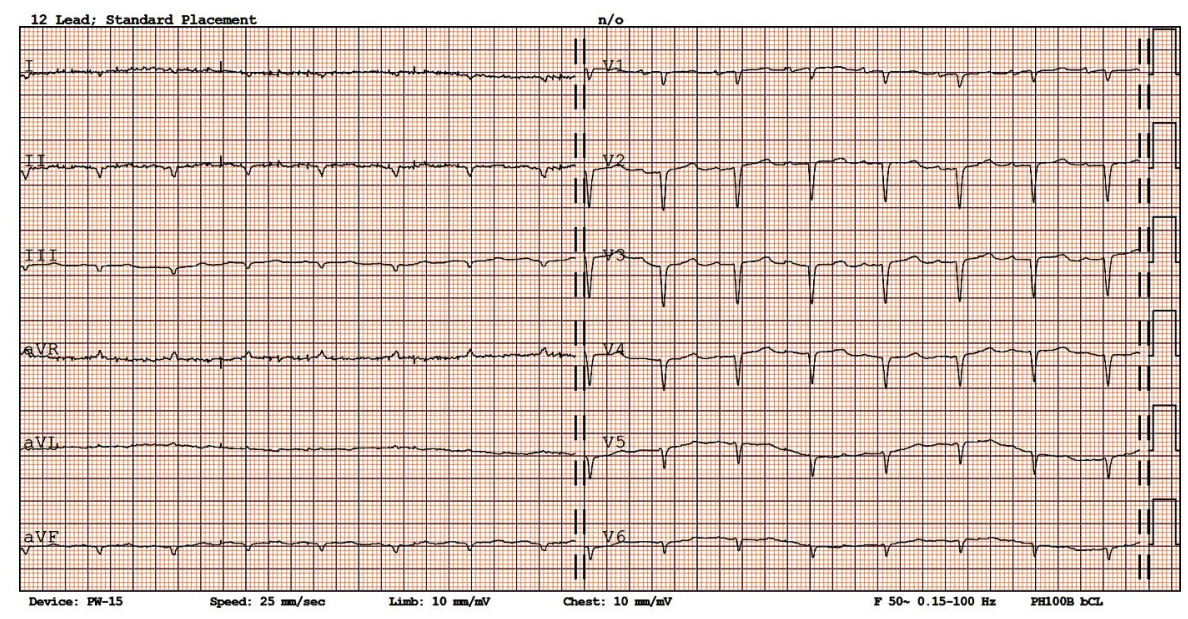

Rycina 3. Elektrokardiogram typowy dla pacjenta z amyloidozą AL. Zwraca uwagę niska amplituda zespołu QRS w odprowadzeniach kończynowych oraz zespołu QS w odprowadzeniach V1-V4 - tak zwany obraz pseudozawału

Figure 3. Electrocardiogram of patient with AL amyloidosis. Typical QRS low voltage in peripheral leads and pseudoinfarct pattern in V1-V4 precordial leads

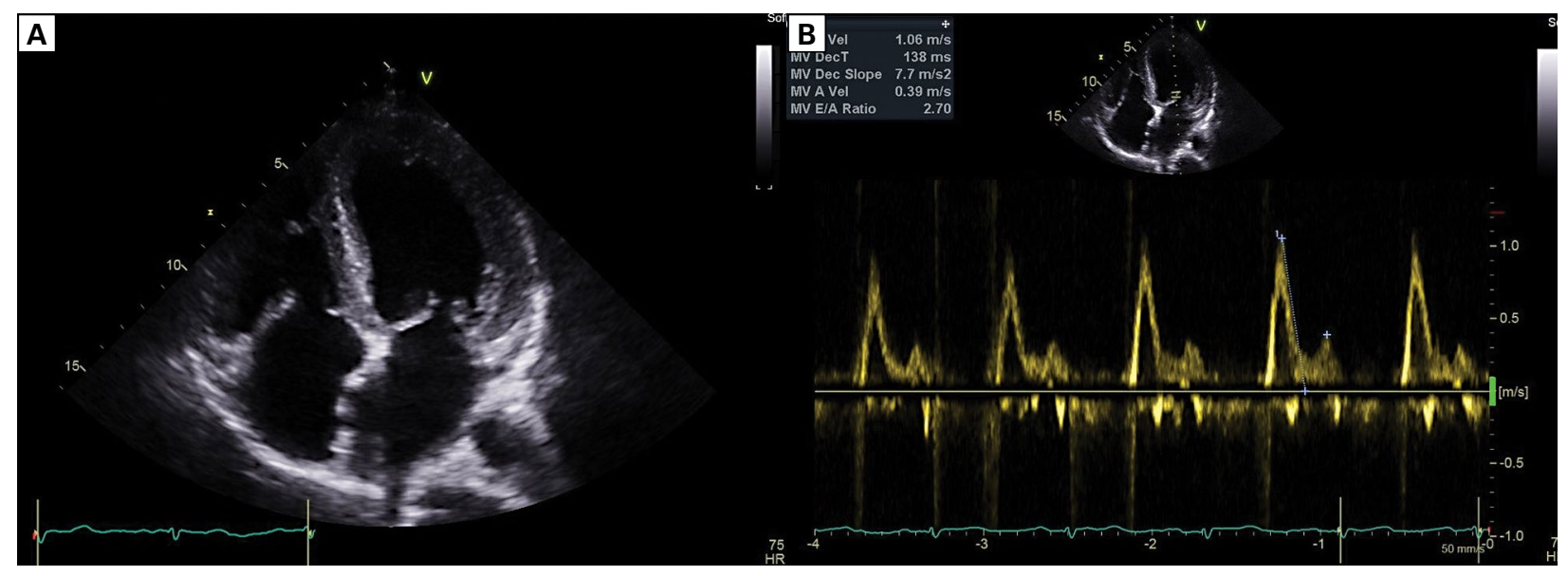

Rycina 4A, B. Echokardiogram pacjenta z zaawansowaną amyloidozą AL: A. Koncentryczne pogrubienie mięśnia lewej komory i wzmożona echogeniczność miokardium najsilniej wyrażona w obrębie przegrody międzykomorowej, pogrubienie przegrody międzyprzedsionkowej i płatków zastawek. Projekcja koniuszkowa czterojamowa; B. Restrykcyjny profil napływu przez zastawkę mitralną (stosunek E/A 2,7). Projekcja koniuszkowa czterojamowa, badanie metodą pulsacyjnej fali doplerowskiej (dzięki uprzejmości dra P. Michałka)

Figure 4A, B. Echocardiographic examination of patient with AL amyloidosis, advanced stage of the disease; A. Concentric left ventricular thickening and hyperechogenicity of the miocardium most visible in interventricular septum, thickening of atrial septum and valvular leaflets. Apical 4-chamber view; B. Restrictive transmitral flow pattern (E/A ratio 2,7). Apical 4-chamber view, pulsed Doppler examination (courtesy of Michalek P.)

zdefiniowano jako pogrubienie mięśnia lewej komory przekraczające $12 \mathrm{~mm}$ bez innej uchwytnej przyczyny i stężenie N-końcowego fragmentu propeptydu natriuretycznego typu B (NT-proBNP, $N$-terminal pro- $B$-type natriuretic peptide) przewyzszające $332 \mathrm{pg} / \mathrm{ml} \mathrm{w}$ przypadku niewystępowaniu $\mathrm{AF}$ ani niewydolności nerek [19].

\section{Elektrokardiogram}

U około $45 \%$ pacjentów $\mathrm{z}$ amyloidozą $\mathrm{AL}$ występują charakterystyczne zmiany w elektrokardiogramie (EKG): niska amplituda zespołu QRS w odprowadzeniach kończynowych oraz zespołu QS w odprowadzeniach V1-V3, które mogą być błędnie interpretowane jako cechy przebytego 
przednio-przegrodowego zawału serca, tak zwany pseudozawał [11] (ryc. 3). Współwystępowanie niskiej amplitudy zespołu QRS w EKG z pogrubieniem mięśnia sercowego stwierdzanym $\mathrm{w}$ badaniu echokardiograficznym silnie przemawia za amyloidozą [20]. Wykazano, że pofragmentowany zespół QRS (fQRS), zdefiniowany jako zespół QRS o różnych odmianach morfologii RSR' węższy niż $120 \mathrm{~ms}$ [21], wiąże się $z$ gorszym rokowaniem u pacjentów $z$ amyloidozą AL [22]. Należy pamiętać, że prawidłowe EKG nie wyklucza amyloidozy. Natomiast cechy przerostu lewej komory w EKG obserwuje się nawet $\mathrm{u}$ około $16 \%$ pacjentów $\mathrm{z}$ amyloidozą AL [19]. W zapisie EKG mogą również być obecne cechy przerostu lewego przedsionka bądź obu przedsionków.

Choć EKG nie może służyć do różnicowania typów amyloidozy, to warto zwrócić uwagę na odrębności w zapisie EKG u chorych na amyloidozę ATTR [23]. Rzadziej stwierdza się niski woltaż w odprowadzeniach kończynowych. Tak zwany obraz „pseudozawału” występuje u 38-63\% pacjentów, ponadto nierzadko stwierdza się małą progresję załamka R w odprowadzeniach kończynowych (u 34\%), AF (nawet do 80\%), wydłużony odstęp PQ (21\%) czy blok lewej odnogi pęczka Hisa (40\%) [24].

\section{Badanie echokardiograficzne}

W badaniu echokardiograficznym u pacjentów $z$ amyloidozą AL stwierdza się wzmożoną, niejednorodną echogeniczność i pogrubienie mięśnia zarówno lewej jak, i prawej komory (ryc. 4). Ponadto charakterystyczne dla amyloidozy jest pogrubienie przegrody międzyprzedsionkowej i płatków zastawek. Uwagę zwraca istotne powiększenie obu przedsionków. Wskazane jest zmierzenie ich wielkości w projekcji koniuszkowej czterojamowej, gdyż wymiar lewego przedsionka $\mathrm{w}$ projekcji przymostkowej w osi długiej lewej komory może być tylko nieznacznie zwiększony. Zaleca się ocenę stopnia dysfunkcji rozkurczowej lewej komory według aktualnych standardów [25]. Należy jednak mieć świadomość, że echokardiograficzne wykładniki restrykcji są trudne do oceny i u pacjenta intensywnie leczonego diuretykami mogą być niedoszacowane [25]. Zaobserwowano, że wraz $z$ postępem choroby nasila się stopień zaburzeń restrykcyjnych [26]. Frakcja wyrzutowa lewej komory mierzona metodą Simpsona długo pozostaje w granicach normy. Bardziej wiarygodną ocenę funkcji skurczowej lewej komory umożliwia analiza odkształcenia (strain) i tempa odkształcenia (strain rate) mięśnia sercowego. Analiza odkształ- cenia podłużnego (longitudinal strain) mięśnia lewej komory metodą śledzenia markerów akustycznych (speckle tracking) wykazuje zazwyczaj nasilone zaburzenia funkcji włókien podłużnych obecne już na wczesnym etapie choroby. Charakterystyczne jest to, że kurczliwość segmentów koniuszkowych może być bliska prawidłowej przy znacznie upośledzonej kurczliwości segmentów podstawnych, co wywołuje tak zwany objaw ,tarczy strzelniczej” (bull's-eye). Objaw ten z czułością 93\% i swoistością $82 \%$ wskazuje na amyloidozę [27]. Istotnym elementem badania echokardiograficznego powinna być ocena wielkości i funkcji prawej komory. Parametry te mają znaczenie rokownicze w amyloidozie AL [28]. Odkształcenie podłużne wolnej ściany prawej komory okazało się jedynym echokardiograficznym predyktorem śmiertelności całkowitej w amyloidozie AL [29]. Wraz z progresją choroby obserwuje się poszerzanie się jamy prawej komory i narastanie niedomykalności trójdzielnej [30]. U połowy pacjentów stwierdza się umiarkowanie zwiększoną ilość płynu w osierdziu [11]. Nierzadko u chorych na amyloidozę AL przy rytmie zatokowym tworzą się skrzepliny w przedsionkach [31]. Można je uwidocznić w przezprzełykowym badaniu echokardiograficznym (TEE, transesophageal echocardiography).

W amyloidozie ATTR grubość mięśnia jest istotnie większa niż w amyloidozie AL i osiąga największy stopień pogrubienia w ATTRwt [24]. Częściej obserwuje się zmniejszenie kurczliwości mięśnia lewej komory wyrażonej pogorszeniem frakcji wyrzutowej, rzadziej natomiast stwierdza się skrzepliny w jamach serca. Poza tym obraz echokardiograficzny amyloidozy ATTR nie różni się istotnie od amyloidozy AL.

Podczas analizy badania echokardiograficznego $\mathrm{u}$ pacjenta $z$ podejrzeniem amyloidozy warto pamiętać, że opisywano zarówno chorych na amyloidozę, u których grubość mięśnia lewej komory pozostawała w normie [32], jak i pacjentów, u których morfologia pogrubienia ściany lewej komory ze względu na asymetryczny charakter przypominała kardiomiopatię przerostową [33].

\section{Rezonans magnetyczny serca}

U pacjentów, u których nie występuje istotnie upośledzona funkcja nerek, nasilona duszność w pozycji leżącej ani klaustrofobia, rezonans magnetyczny serca (CMR, cardiac magnetic resonance) jest cennym narzędziem diagnostycznym, pozwalającym $z$ czułością około $80 \%$ i specyficznością około $90 \%$ dokonać rozpoznania amyloidozy serca [34]. Rezonans magnetyczny serca niejednokrotnie 
ma przewagę nad badaniem echokardiograficznym w ocenie wielkości i funkcji prawej komory. Może uwidocznić skrzepliny w jamach serca. Rozlane początkowo podwsierdziowe, następnie pełnościenne obszary późnego wzmocnienia pokontarstowego (LGE, late-gadolinium enhancement) są typową cechą amyloidozy serca w badaniu rezonansu magnetycznego. Amyloidoza jest jedną z nielicznych patologii, w której obszary LGE rejestruje się również w obrębie przedsionków [35]. Niestety, na wczesnym etapie choroby obszary LGE moga nie być widoczne [36]. Trudności z wyzerowaniem sygnału $z$ mięśnia sercowego po podaniu środka kontrastowego są unikatową cechą amyloidozy. Na podstawie charakteru zmian w CMR nie można jednak ustalić typu amyloidozy [9]. Ponadto CMR pozwala ocenić wielkość przestrzeni zewnątrzkomórkowej, która w amyloidozie jest utożsamiana $z$ tak zwanym ładunkiem amyloidu. Parametr ten, podobnie jak rozległość obszarów późnego wzmocnienia pokontrastowego, ma znaczenie rokownicze [37]. Sugeruje się, że rezonans magnetyczny może wspomagać ocenę odpowiedzi serca na leczenie hematologiczne [38].

\section{Biomarkery kardiologiczne}

Ważnym elementem diagnostyki chorego na amyloidozę serca są biomarkery kardiologiczne oceniane w surowicy - troponina T i NT-proBNP. Stężenie NT-proBNP jest szczególnie wysokie $\mathrm{w}$ amyloidozie AL, gdyż FLC stymulują ekspresję genu dla NT-proBNP [39]. Natomiast stężenie NT-proBNP poniżej $55 \mathrm{pg} / \mathrm{ml}$ u pacjenta $z$ amyloidozą AL wyklucza zajęcie serca [40]. Oznaczenie stężenia obu markerów jest niezbędne do oceny zaawansowania klinicznego amyloidozy według klasyfikacji Mayo Clinic [41]. Mimo że stężenie NT-proBNP zależy od funkcji nerek, to uważa się, $\dot{z}$ e umożliwia wiarygodne przewidywanie przeżycia $\mathrm{w}$ amyloidozie AL przy oszacowanym wskaźniku przesączania kłębuszkowego (eGFR, estimated glomerular filtration rate) ponad $15 \mathrm{ml} / \mathrm{min} / 1,73$ $\mathrm{m}^{2}[42,43]$. Obecnie zaleca się, aby stężenie NT-proBNP było uwzględniane zarówno w kwalifikacji pacjenta do przeszczepienia autologicznych krwiotwórczych komórek macierzystych (auto-HSCT, autologous hematopoietic stem cell transplantation), jak i w ocenie skuteczności chemioterapii [44, 45]. Za kryterium odpowiedzi serca na leczenie hematologiczne uważa się obniżenie stężenia NT-proBNP o więcej niż $300 \mathrm{pg} / \mathrm{ml}$ i minimum 30\% w stosunku do stężenia wyjściowego $650 \mathrm{pg} / \mathrm{ml} \mathrm{lub}$ wyższego [45]. Ostatnio zauważono, że bardziej znaczne obniżenie się stężenia NT-proBNP w od- powiedzi na leczenie hematologiczne wskazuje na lepsze rokowanie. Tak zwaną głęboką odpowiedź narządową w odniesieniu do serca zdefiniowano jako obniżenie się stężenia NT-proBNP do wartości poniżej $400 \mathrm{pg} / \mathrm{ml}$ [46].

Zwraca się uwagę, że obserwowany w niedługim czasie po podaniu chemioterapii wzrost stężenia NT-proBNP może nie wynikać $z$ nasilenia HF $[47,48]$. Dlatego w tym okresie duże znaczenie ma ocena kliniczna pacjenta, zwłaszcza w odniesieniu do decyzji o intensywności leczenia hematologicznego.

Wykazano przydatność kliniczną nowych biomarkerów - rozpuszczalnej izoformy białka ST2 (sST2, soluble suppression of tumorigenicity 2) oraz różnicującego czynnika wzrostu 15 (GDF-15, growth differentiation factor 15) - u chorych na amyloidozę AL [49-51]. Dołączenie sST2 do klasyfikacji zaawansowania klinicznego amyloidozy zwiększa zdolności predykcyjne tej klasyfikacji. Na podstawie badań dwóch niezależnych kohort pacjentów potwierdzono, że GDF-15 jest dobrym predyktorem zarówno śmiertelności całkowitej, jak i progresji choroby nerek u pacjentów $z$ amyloidozą, $z$ kolei obniżenie wartości tego biomarkera w odpowiedzi na leczenie wiąże się z lepszym rokowaniem [52].

W amyloidozie TTR stężenie NT-proBNP jest zazwyczaj niższe niż w amyloidozie AL i koreluje z grubością mięśnia. Najniższe stężenia NT-proBNP obserwuje się w ATTRwt. Zauważono, że u pacjenta powyżej 70. roku życia $z$ amyloidozą, u którego stwierdza się stężenie NT-proBNP niższe niż $1430 \mathrm{pmol} / \mathrm{l}$, najczęściej występuje amyloidoza TTR typu dzikiego [2].

\section{Wolne łańcuchy lekkie}

Wartościowym badaniem laboratoryjnym, którego wykonanie nie powinno być ograniczone jedyne do ośrodków hematologicznych, jest ocena stosunku FLC kappa i FLC lambda w surowicy. Nieprawidłowy wynik tego badania stwierdza się u ponad $90 \%$ chorych na amyloidozę AL [53]. Sugeruje się, że aby zwiększyć szansę wczesnego rozpoznania amyloidozy AL, powinno się oznaczać stosunek FLC u wszystkich pacjentów $z$ niewydolnością serca $z$ zachowaną frakcją wyrzutową (HFpEF, heart failure with preserved ejection fraction) [19]. Oznaczenie stężenia FLC immunoglobulin w surowicy u pacjenta $z$ amyloidozą AL pozwoli wyliczyć parametr oznaczany skrótem dFLC (difference between involved and uninvolved serum immunoglobulin free light chain levels), tj. różnicę między stężeniem łańcuchów lekkich odpowiedzialnych za chorobę 
i łańcuchów lekkich prawidłowych. Parametr ten ma znaczenie rokownicze i jest uwzględniony w klasyfikacji zaawansowania klinicznego amyloidozy AL według Mayo Clinic [54].

Należy pamiętać, że nawet u około $20 \%$ chorych na amyloidozę ATTR stwierdza się obecność białka monoklonalnego, co stwarza trudności diagnostyczne $[55,56]$.

\section{Badania wysiłkowe}

Próba wysiłkowa nie pozwala ocenić ryzyka choroby wieńcowej u pacjenta $z$ amyloidozą AL. Jak wyżej wspomniano, pacjenci często odczuwają bóle wysiłkowe, nawet mimo prawidłowych tętnic wieńcowych. W badaniach czynnościowych wykazano, że dysfunkcja mikrokrążenia wieńcowego w amyloidozie AL jest częsta [57]. Dlatego w ramach diagnostyki bólów w klatce piersiowej zasadne wydaje się zastąpienie koronarografii tomografią tętnic wieńcowych jako badaniem mniej inwazyjnym, zwłaszcza jeśli pacjent nie jest obciążony typowymi czynnikami ryzyka miażdżycy. Ergospirometrię wykonuje się jedynie w ramach kwalifikacji chorego na amyloidozę do przeszczepienia serca. W dalszej części niniejszego artykułu opisano, u których chorych na amyloidozę AL należałoby rozważyć tę metodę leczenia.

Natomiast badaniem, które pozwoli zobiektywizować obniżenie wydolności fizycznej pacjenta $z$ amyloidozą $\mathrm{AL}$, jest test 6 -minutowego marszu (6MWT, 6-minute walk test). Dowiedziono, że wynik 6MWT umożliwia poprawne przewidywanie przeżycia u chorego na amyloidozę AL [58]. Pomaga również ocenić poprawę wydolności serca u pacjenta po rozpoczęciu leczenia hematologicznego, szczególnie w początkowym okresie, kiedy opieranie się na stężeniach biomarkerów kardiologicznych mogłoby być mylące [59].

\section{Biopsja}

Biopsja endomiokardialna powinna być wykonana, jeśli u pacjenta $z$ echokardiograficznym obrazem amyloidozy serca nie udało się ustalić rozpoznania za pomocą biopsji łatwiej dostępnych narządów. Taka sytuacja dotyczy nie więcej niż $15 \%$ pacjentów $z$ amyloidozą AL [60]. Warto pamiętać, że czułość biopsji serca w wykrywaniu amyloidozy sięga $100 \%$ pod warunkiem pobrania reprezentatywnych wycinków [61]. W doświadczonych ośrodkach ryzyko groźnych powikłań nie przekracza 1\% [62]. Ze względu na dużą spoistość mięśnia sercowego w przebiegu amyloidozy ryzyko przebicia ściany serca jest niższe niż na przykład w zapaleniu mięśnia sercowego. Biopsja serca u chorego na amyloidozę AL powinna być poprzedzona oceną echokardiograficzną, ponieważ w przebiegu choroby często obserwuje się zwiększoną ilość płynu w worku osierdziowym. Jednocześnie należy mieć świadomość, że w przypadku wystąpienia tamponady $\mathrm{w}$ związku $\mathrm{z}$ biopsją serca $\mathrm{w}$ badaniu echokardiograficznym może nie być widoczne zapadanie się prawego przedsionka czy prawej komory $z$ powodu wysokiego ciśnienia $\mathrm{w}$ prawych jamach serca i zwiększonej sztywności ich ścian [9]. W takiej sytuacji rozpoznania tamponady powinno się dokonać na podstawie obrazu klinicznego.

Uważa się, że wybór miejsca biopsji w celu potwierdzenia amyloidozy powinien być dokonany zgodnie $z$ doświadczeniem danego ośrodka $[4,19]$ - z zastrzeżeniem, że należy unikać biopsji dziąsła jako badania o szczególnie niskiej czułości i zastąpić ją biopsją ślinianki wargi dolnej. Jednocześnie nie zaleca się wykonania przezskórnej biopsji wątroby czy nerki u pacjenta $z$ istotnym klinicznie podejrzeniem amyloidozy AL $z$ powodu zwiększonego ryzyka krwawienia. Najmniej inwazyjna jest biopsja aspiracyjna tkanki tłuszczowej, którą można wykonać u pacjenta leczonego przeciwkrzepliwie, choć nawet w najbardziej doświadczonych ośrodkach czułość tej metody w wykrywaniu amyloidozy AL wynosi około 75\% [63]. Jeśli pacjent zgłasza objawy dyspeptyczne i chudnięcie, to cennym materiałem są wycinki z żołądka lub dwunastnicy (ryc. 5). Wycinki te powinny być pobrane nawet w przypadku stwierdzenia makroskopowo prawidłowej błony śluzowej, co zdarza się u około $35 \%$ chorych z zajęciem górnego odcinka przewodu pokarmowego w przebiegu amyloidozy AL [12].

Należy ustalić, czy u pacjenta $z$ podejrzeniem amyloidozy nie wykonywano wcześniej badań endoskopowych lub innych biopsji. Uzupełnienie oceny histopatologicznej wcześniej pobranych wycinków o barwienia w kierunku amyloidozy może znacząco skrócić diagnostykę i zmniejszyć liczbę procedur inwazyjnych, którym trzeba poddać pacjenta. Każdorazowo w przypadku podejrzenia amyloidozy należy zamieścić informację na temat takiego podejrzenia na skierowaniu na badanie histopatologiczne, ponieważ diagnostyka amyloidozy wymaga wykonania specjalnych barwień.

Wybierając miejsce biopsji, należy mieć również na uwadze czas do uzyskania rozpoznania. Ma to szczególne znaczenie w tej jednostce chorobowej ze względu na jej częstą szybką progresję. Nie jest więc błędem wykonanie kilku biopsji jednoczasowo, aby zwiększyć szansę na jak najszybsze wykrycie amyloidu. 


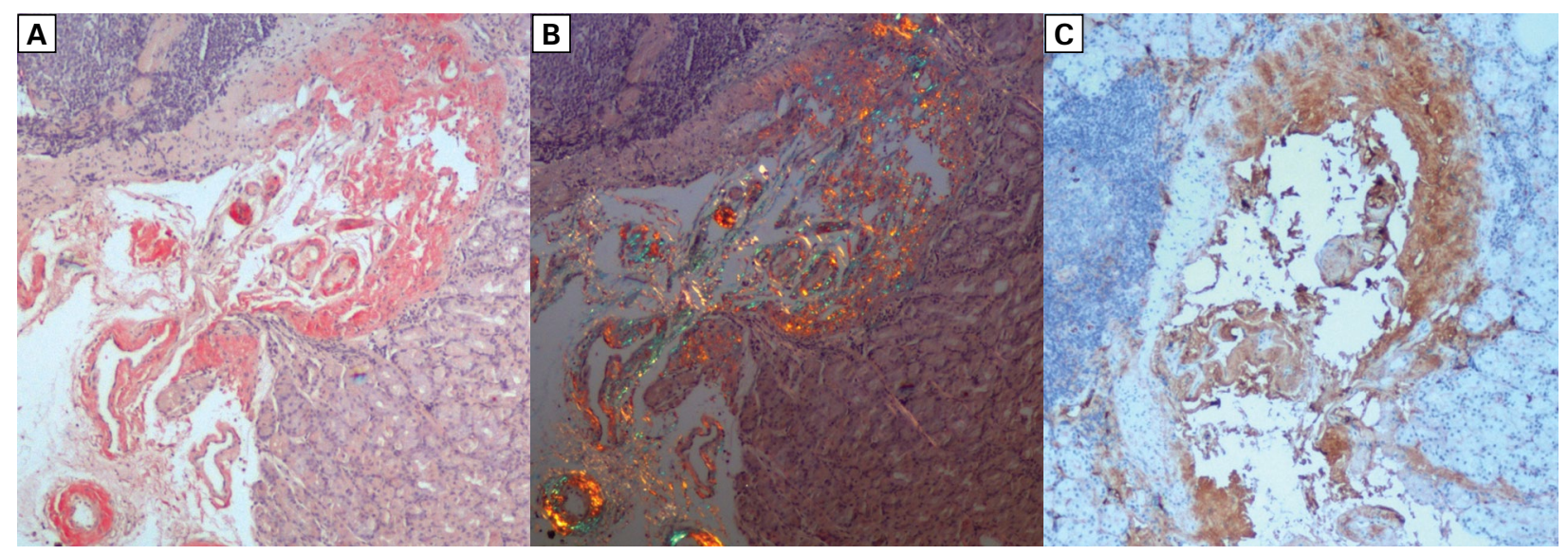

Rycina 5A-C. Badanie histopatologiczne wycinków z żołądka pobranych podczas gastroskopii u pacjenta z kardiomiopatią restrykcyjną, objawami dyspeptycznymi i istotnym chudnięciem: A. Różowe złogi amyloidu w błonie śluzowej (barwienie czerwienią Kongo w środowisku fenolu, powiększenie $\times 400$ ); B. Zielone świecenie złogów amyloidu w świetle spolaryzowanym (barwienie czerwienią Kongo w środowisku fenolu, powiększenie $\times 400$ ); C. Typowanie amyloidu za pomocą reakcji immunohistochemicznych. Dodatnia reakcja z przeciwciałem przeciwko łańcuchom lekkim typu lambda (kolor brązowy) i kolokalizacja ze złogami amyloidu ujawnionymi w barwieniu czerwienią Kongo potwierdzają rozpoznanie amyloidozy łańcuchów lekkich (powiększenie $\times 400$; dzięki uprzejmości dr M. Legatowicz-Koprowskiej i dr E. Walczak)

Figure 5A-C. Histopathological examination of gastric biopsy gained during endoscopy of patient with restrictive cardiomyopathy, dyspepsia and severe weight loss: A. Pink amyloid deposits in mucous membrane (phenol Congo red staining, $\times 400$ ); B. Typical apple-green birefringence of amyloid deposits viewed under cross-polarized light (phenol Congo red staining, $\times 400$ ); C. Identification of amyloid deposits' type by immunohistochemical reaction with anti-lambda monoclonal antibodies. Brown areas display positive reaction. Colocalization of brown areas and Congo red positive amyloid deposits confirm the diagnosis of light-chain amyloidosis $(\times 400$; courtesy of LegatowiczKoprowska M. and Walczak E.)

Kluczowe znaczenie dla dokonania ostatecznego rozpoznania ma typowanie złogów amyloidu. Za metodę referencyjną uznaje się spektrometrię masową złogów wyodrębnionych laserowo $z$ wycinków ocenianych w mikroskopie elektronowym [4]. Dużą czułość i specyficzność uzyskuje się, analizując w mikroskopie elektronowym wycinki barwione techniką immunogold [64]. Należy zaznaczyć, że obie metody są kosztowne. W Polsce, jak dotąd, typowanie amyloidu przeprowadza się wyłącznie za pomocą reakcji $z$ komercyjnymi przeciwciałami monoklonalnymi metodą immunohistochemiczną. Choć wyprofilowane pracownie histopatologiczne przy użyciu immunohistochemii uzyskują bardzo wysoki odsetek prawidłowych rozpoznań, to czynione są starania, aby możliwe było ustalanie typu amyloidu uznanymi metodami.

W sytuacji, kiedy u danego pacjenta uzyskuje się pozytywne reakcje zarówno $z$ przeciwciałami przeciw łańcuchom lekkim, jak i z przeciwciałami przeciw ATTR, warto rozważyć przesłanie wycinków utrwalonych w bloczkach parafinowych do zakładu patomorfologii $z$ dużym doświadczeniem w diagnozowaniu amyloidozy w Polsce lub do referencyjnego centrum amyloidozy za granicą.

Należy zaznaczyć, że czułość biopsji aspiracyjnej tkanki tłuszczowej w wykrywaniu amyloidozy ATTR jest niska i wynosi około $45 \%$ w przypadku postaci uwarunkowanej genetycznie i tylko $15 \%$ w przypadku postaci typu dzikiego [63].

\section{Scyntygrafia}

Dużym wsparciem przy różnicowaniu amyloidozy AL i amyloidozy ATTR jest scyntygrafia całego ciała $z$ wykorzystaniem znaczników używanych pierwotnie do badania kości - Tc-99m DPD (3,3-diphosphono-1,2-propanodicarboxylic acid) i Tc-99m PYP (pyrophosphate). Nie jest do końca wyjaśnione, dlaczego $\mathrm{w}$ obu typach amyloidozy ATTR uzyskuje się bardzo duży wychwyt tych znaczników w obrębie serca w odróżnieniu od amyloidozy AL, w której wychwyt znacznika w sercu nie występuje. Warto zaznaczyć, że scyntygrafia pozwala wykazać zajęcie serca u chorego na amyloidozę ATTR, zanim zmiany są widoczne w badaniu echokardiograficznym czy w CMR. Czułość 
i swoistość scyntygrafii w wykrywaniu amyloidozy ATTR jest wysoka i wynosi, odpowiednio, 97\% i 100\% [65]. U pacjenta, u którego wyniki badań hematologicznych (stosunek FLC w surowicy, immunofiksacja białek surowicy i białek $z$ dobowej zbiórki moczu) są negatywne i jednocześnie występuje znaczny wychwyt znacznika w obrębie serca w scyntygrafii, akceptowalne jest rozpoznanie amyloidozy TTR bez wykonywania biopsji [66].

\section{Badanie genetyczne}

Kilka laboratoriów w Polsce wykonuje badanie genetyczne w kierunku amyloidozy ATTR [67]. Oczywiście badanie to u pacjenta $z$ niejednoznacznym wynikiem biopsji narządu (dodatnie reakcje immunohistochemiczne $z$ przeciwciałami przeciw łańcuchom lekkim i przeciw TTR) może potwierdzić ATTRm, ale nie wykluczy ATTRwt. Uważa się natomiast, że u każdego pacjenta $\mathrm{z}$ amyloidozą TTR powinno się wykonać badanie genetyczne, ponieważ przebieg choroby, rokowanie i niekiedy sposoby leczenia znacznie się różnią w zależności od typu mutacji [2].

\section{Leczenie}

\section{Leczenie kardiologiczne}

Należy mieć świadomość, że nie ma prospektywnych badań randomizowanych dotyczących leczenia wspomagającego chorych na amyloidozę serca. Podstawą zaleceń są badania obserwacyjne lub opinie ekspertów [4, 9, 68]. Leczenie pacjenta $\mathrm{z}$ amyloidozą wymaga współpracy specjalistów $z$ wielu dziedzin medycyny. Poszczególne zalecenia powinny być traktowane $z$ dużą ostrożnością i indywidualnie dopasowywane do sytuacji klinicznej danej osoby.

Ponadto u pacjentów $\mathrm{z}$ amyloidozą AL często obserwuje się zwiększoną toksyczność stosowanej terapii. Może to wynikać $z$ zajęcia wątroby w przebiegu AL, $z$ niewydolności wątroby pochodzenia sercowego lub $z$ częstej $w$ tej grupie pacjentów obniżonej wydolności nerek, a także $z$ faktu, że amyloidoza AL jako choroba ogólnoustrojowa zaburza funkcje wielu organów i układów. $Z$ tych względów dla tej grupy pacjentów jest wyjątkowo ważne, aby stosować najmniejszą skuteczną dawkę leku i unikać polipragmazji.

Największą poprawę funkcji serca u chorego na amyloidozę AL można uzyskać dzięki obniżeniu stężenia FLC. Dlatego farmakologiczne postępowanie kardiologiczne ma jedynie znaczenie uzupełniające względem terapii cytoredukcyjnej.
W celu leczenia przewodnienia zaleca się, aby pacjent ograniczył ilość przyjmowanych płynów do $1,5 \mathrm{l} /$ dobę i unikał spożywania nadmiernych ilości soli. W przypadku konieczności leczenia farmakologicznego zastoinowej HF główną rolę odgrywają diuretyki pętlowe. Antagoniści receptora dla aldosteronu mają znaczenie uzupełniające. Leczenie diuretyczne powinno być prowadzone $z$ dużą ostrożnością. Zarówno ciśnienie tętnicze, jak i stężenia sodu i potasu oraz funkcja nerek podczas leczenia diuretycznego powinny być ściśle kontrolowane. $Z$ powodu niebezpieczeństwa obrzęku w obrębie błony śluzowej przewodu pokarmowego i zaburzeń wchłaniania $z$ przewodu pokarmowego często konieczne jest dożylne podawanie diuretyków. Podczas leczenia diuretycznego należy się liczyć z ryzykiem nasilenia się hipoalbuminemii i dalszego narastania obrzęków.

$\mathrm{U}$ pacjentów $\mathrm{Z}$ amyloidozą $\mathrm{AL}$ obserwuje się kompensacyjną tachykardię zatokową. $\mathrm{W}$ monitorowaniu metodą Holtera uwagę zwraca brak zmienności dobowej częstości rytmu serca. Nie zaleca się spowalniania czynności serca w obrębie rytmu zatokowego lekami beta-adrenolitycznymi ze względu na ryzyko bradyarytmii i zaburzeń przewodzenia. Ponadto u chorych na amyloidoze AL beta-adrenolityki wykazują silne działanie kardiodepresyjne i hipotensyjne. Natomiast wybór leku do kontroli częstości rytmu serca w obrębie AF pozostaje dyskusyjny. Część kardiologów zaleca małe dawki digoksyny [4], inni stosują $\mathrm{w}$ tym celu małe dawki beta-adrenolityków [69] lub amiodaronu [9]. Zaobserwowano, że digoksyna $\mathrm{w}$ warunkach ex vivo wiązała się ze złogami amyloidu i $z$ tego względu należy się liczyć z niebezpieczeństwem miejscowej toksyczności leku. W klinicznych badaniach obserwacyjnych wykazano, że digoksyna stosowana w małych dawkach, tak aby stężenie leku utrzymywało się tuż poniżej dolnej granicy przedziału terapeutycznego, może być bezpiecznie podawana pacjentom $z$ amyloidozą AL pod warunkiem częstego monitorowania zarówno stężenia digoksyny, jak i stężenia potasu oraz korygowania jego niedoboru [70].

Według niektórych ekspertów amiodaron może być stosowany w celu opanowania arytmii komorowych u pacjentów $z$ amyloidozą $\operatorname{AL}[4,9]$. Ze względu na wspominaną wrażliwość tej grupy chorych na toksyczne działanie leków terapia amiodaronem będzie wymagała częstej kontroli aktywności enzymów wątrobowych. Ponadto wątpliwości związane $z$ bezpieczeństwem amiodaronu wynikają $z$ nierzadko występującej w amyloidozie AL niedoczynności tarczycy [71]. 
W związku z leczeniem diuretycznym i przyjmowaniem glikokortykosteroidów pacjent $z$ amyloidozą AL niejednokrotnie wymaga suplementacji potasu. Jednocześnie na każdym etapie choroby należy się liczyć $z$ niebezpieczeństwem wystąpienia niewydolności nerek, co nakazuje dużą ostrożność w uzupełnianiu potasu.

W leczeniu hipotensji ortostatycznej skuteczna jest midodryna, której aktywny metabolit działa wybiórczo na obwodowe receptory alfa ${ }_{1-}$ -adrenergiczne, zwiększając opór obwodowy. Co więcej, u chorych na amyloidozę AL nie obserwowano charakterystycznego dla midodryny działania niepożądanego, jakim jest nadciśnienie tętnicze w pozycji leżącej [9].

Natomiast lekami, których nie powinno się stosować u chorych na amyloidozę AL, są inhibitory konwertazy angiotensyny, antagoniści receptora dla angiotensyny (sartany) oraz antagoniści wapnia. Wykazują one silne działanie hipotensyjne w tej grupie pacjentów [69] lub wręcz zwiększają ryzyko zgonu [72, 73]. U pacjentów we wstrząsie kardiogennym w przebiegu amyloidozy AL leczonych wlewem dobutaminy, a w razie konieczności również noradrenaliny i lewosimendanu, stwierdzano wysoką, około 80-procentową (81\%), śmiertelność w ciągu około 5 dni od rozpoczęcia wlewu (mediana 5 dni; przedział międzykwartylowy 3-9 dni). Mimo zwiększania dawek amin katecholowych nie uzyskiwano wzrostu średniego ciśnienia tętniczego ani rzutu serca [74].

Zasady farmakologicznego leczenia kardiologicznego $\mathrm{w}$ amyloidozie ATTR są podobne i również opierają się głównie na opiniach ekspertów [23].

\section{Leczenie przeciwkrzepliwe}

Trudnym i nierozwiązanym zagadnieniem pozostaje leczenie przeciwkrzepliwe. Amyloidoza AL wiąże się ze zwiększonym ryzykiem krwawienia głównie $z$ powodu kruchości naczyń, w obrębie których odkłada się amyloid. U 9-14\% pacjentów obserwuje się obniżoną aktywność czynnika X, który wiąże się ze złogami amyloidu [75, 76]. Połowa $z$ tej grupy chorych doświadcza istotnych krwawień. Opublikowano pojedyncze doniesienia o nabytych niedoborach innych czynników krzepnięcia w przebiegu amyloidozy AL, na przykład czynnika IX [77]. Natomiast zespół nerczycowy w przebiegu amyloidozy AL sprzyja incydentom zatorowym. Obserwowano silny związek między niskim stężeniem albumin w surowicy a częstością powikłań zatorowych [78]. Podobne znaczenie ma obniżona aktywność antytrombiny III [79] czy — jak ostatnio wykazano - wysoka wartość dFLC oraz podwyższone stężenie beta ${ }_{2}$-mikroglobuliny [80].

Chorzy na amyloidozę AL nie odnoszą korzyści $z$ profilaktycznego leczenia przeciwkrzepliwego $\mathrm{w}$ związku z HF. Często natomiast występują $\mathrm{u}$ nich wskazania do antykoagulacji $z$ powodu AF. Jednocześnie nawet u $35 \%$ pacjentów spotyka się skrzepliny w przedsionkach i skrzepliny mogą powstawać również w przypadku rytmu zatokowego [81]. Dlatego sugeruje się rozważenie leczenia przeciwkrzepliwego, jeśli w badaniu echokardiograficznym stwierdzono obniżoną funkcję skurczową przedsionków, czyli fala A w profilu napływu mitralnego nie przekracza $20 \mathrm{~cm} / \mathrm{s}$ [9]. W leczeniu przeciwkrzepliwym stosuje się heparyny drobnocząsteczkowe lub antagonistów witaminy $\mathrm{K}$ [4, 9]. Ze względu na wspomnianą kruchość naczyń zasadne są zmniejszenie standardowo podawanych dawek leków przeciwkrzepliwych oraz częsta kontrola pacjenta pod kątem ewentualnych objawów krwawienia.

Optymalne byłoby oznaczenie aktywności czynnika $\mathrm{X}$ przed rozpoczęciem podawania heparyny. Krwawienia w przebiegu amyloidozy AL powinny być leczone standardowo. Zaleca się stosowanie koncentratów czynnika $\mathrm{X}$ jedynie $\mathrm{w}$ przypadku jego udokumentowanego niedoboru. Należy liczyć się z tym, że preparaty te mogą wykazywać skrócony okres półtrwania u chorych na amyloidozę AL z powodu wiązania się czynnika $\mathrm{X}$ ze złogami amyloidu [68].

Eksperci wyrażają opinię, że chorych na amyloidozę AL można leczyć przeciwkrzepliwie doustnymi antykoagulantami - apiksabanem, dabigatranem lub riwaroksabanem [82]. Pojawiają się głosy, że być może przezskórne zamknięcie uszka lewego przedsionka po wstępnym okresie koniecznego leczenia przeciwkrzepliwego pozwoliłoby $\mathrm{w}$ dalszej perspektywie zrezygnować $z$ antykoagulacji. Opinii tych nie podzielają jednak wszyscy eksperci zgromadzeni na XVI Zjeździe Międzynarodowego Stowarzyszenia Amyloidozy (the XVIth International Symposium on Amyloidosis, 2018 r.)

Badacze są zgodni, że optymalne leczenie przeciwkrzepliwe pacjentów $z$ amyloidozą AL jest trudnym zagadnieniem i wymaga dalszych analiz. Sytuację dodatkowo komplikuje fakt, że leczenie hematologiczne może zarówno nasilić tendencję do krwawień (np. małopłytkowość związana $z$ terapia), jak i zwiększać ryzyko incydentu zatorowego (np. terapia talidomidem). Chorzy na amyloidozę ATTR często wymagają leczenia przeciwkrzepliwego ze względu na powszechnie występujące AF. Zgodnie $z$ opiniami ekspertów stosuje się antagonistów 
witaminy K lub nowe doustne antykoagulanty niebędące antagonistami witaminy $\mathrm{K}$ (NOAC, new oral anticoagulants) [23, 82].

\section{Doksycyklina}

Wykazano, że inkubacja $z$ zastosowaniem doksycykliny złogów amyloidu wypreparowanych $z$ materiału autopsyjnego pochodzącego od pacjenta $z$ amyloidozą AL prowadziła do rozkładania tych złogów [83]. Zauważono, że pacjenci $z$ amyloidozą AL serca, którzy podczas chemioterapii przyjmowali doksycyklinę w profilaktyce zakażeń w dawce dobowej $200 \mathrm{mg}$, przeżywali dłużej niż pacjenci otrzymujący penicylinę $[84,85]$. Korzystne działanie doksycykliny obserwowano równiez u chorych na amyloidozę ATTR [86]. Optymistyczne doniesienia wymagają potwierdzenia w dalszych badaniach. Planuje się prospektywne randomizowane badanie dotyczące wpływu doksycykliny na rokowanie chorych na amyloidozę [64].

\section{Elektroterapia}

Jak dotąd, nie wykazano jednoznacznych korzyści $z$ wszczepiania układów stymulujących serce ani implantowalnych kardiowerterów-defibrylatorów (ICD, implantable cardioverter-defibrillator) u pacjentów $\mathrm{z}$ amyloidozą $\mathrm{AL}$ $z$ zajęciem serca. Choć donoszono o skutecznych interwencjach kardiowerterów, to nie przekładało się to na zmniejszenie śmiertelności w tej grupie [87]. Jak wykazano w badaniu, w którym rejestratory zaburzeń rytmu serca wszczepiono 20 chorym ze schyłkową HF w przebiegu amyloidozy AL, większość pacjentów umiera $z$ powodu zatrzymania krążenia w mechanizmie aktywności elektrycznej bez tętna (PEA, pulseless electrical activity) [88]. Istotne komorowe zaburzenia rytmu serca są rzadszym problemem w amyloidozie serca [16] i dość dobrze odpowiadają na leczenie amiodaronem. Ze względu na sztywność płatków zastawki trójdzielnej wszczepienie elektrody do prawej komory u pacjenta $z$ amyloidozą wiąże się ze zwiększonym ryzykiem wywołania lub nasilenia już istniejącej niedomykalności trójdzielnej [9]. Wobec niezadowalającej ilości danych usprawiedliwione wydaje się podejście, aby wskazania do elektroterapii u każdego chorego na amyloidozę AL były rozpatrywane indywidualnie w zależności od stopnia zaawansowania i przebiegu choroby, planowanego leczenia oraz przewidywanego rokowania.

Na podstawie wyników badań obserwacyjnych wydaje się, że ablacja nie może być zalecaną metodą leczenia AF u chorych na amyloidozę AL ze wzglę- du na duży odsetek nawrotu arytmii w związku $z$ postępem choroby [8].

W amyloidozie ATTR znacznie częściej niż w amyloidozie AL obserwuje się zaburzenia przewodzenia przedsionkowo-komorowego. Na podstawie badań obserwacyjnych ustalono, że w ATTRm układ stymulujący serca wszczepiono 25-36\% pacjentów (zależnie od typu mutacji), natomiast w ATTRwt $43 \%$ pacjentów [2]. Najczęstsze przyczyny wszczepienia układów stymulujących serce obejmowały: zaawansowany blok przedsionkowo-komorowy, objawową bradykardię, AF z wolną czynnością komór. Nie udało się jednoznacznie wykazać skuteczności takiego postępowania w obniżaniu śmiertelności chorych na amyloidozę TTR. W rejestracji EKG metodą Holtera u 88\% pacjentów z ATTRwt i u $12 \%$ pacjentów z ATTRm typu V122I stwierdzano nieutrwalone częstoskurcze komorowe (nsVT, non-sustained ventricular tachycardia). Obecność częstoskurczów nie wiązała się z gorszym rokowaniem. Wiadomo, że u pacjentów $z$ amyloidozą ATTR rzadziej obserwowano adekwatne wyładowania ICD [2]. Dlatego decyzja o wszczepieniu ICD u pacjenta $z$ amyloidozą ATTR jest trudna i każdorazowo wymaga indywidualnego rozpatrzenia. Niektórzy autorzy postulują, by wszczepienie ICD pacjentowi z amyloidozą ATTR rozważać, jeśli rejestruje się liczne epizody nsVT lub epizody utrwalonych częstoskurczów komorowych albo jeśli chory oczekuje na przeszczepienie serca [2].

\section{Przeszczepianie serca i systemy wspomagania serca}

Uważa się, że w niektórych sytuacjach pacjent z HF w przebiegu amyloidozy AL może być rozważany jako kandydat na biorcę serca. Dotyczy to około 5\% pacjentów, u których stwierdzono izolowane zajęcie serca [9]. Jak rzadka jest to sytuacja najlepiej odzwierciedla fakt, że w Mayo Clinic w okresie 20 lat na ponad 3 tys. pacjentów $z$ amyloidozą AL $z$ zajęciem serca tylko 23 przeszczepiono ten organ [90]. Poza izolowanym zajęciem serca inne warunki, jakie spełniali ci chorzy, to wiek ponizej 60 lat i niewystępowanie szpiczaka plazmocytowego. Uważa się, że intensywne leczenie hematologiczne za pomocą auto-HSCT lub chemioterapii powinno być rozpoczęte $\mathrm{w}$ niedługim czasie po przeszczepieniu serca. Mediana przė̇ycia pacjentów po przeszczepieniu serca, którzy uzyskali całkowitą remisję hematologiczną, wynosiła 10,8 roku w porównaniu z medianą przeżycia całej grupy wynoszącą 3,5 roku [90]. Chorzy na amyloidozę AL oczekujący na przeszczepienie serca i pozostający bez 
leczenia hematologicznego przeżywają krócej niż pacjenci z HF o innej etiologii. Dlatego w niektórych ośrodkach rozpoczyna się chemioterapię u chorych na amyloidozę AL kwalifikowanych do przeszczepienia serca i w przypadku uzyskania poprawy weryfikuje się wskazania do takiego przeszczepienia [9, 91]. Wyniki badań nie pozwalają jednoznacznie ocenić przeszczepienia serca jako metody leczenia amyloidozy AL ze względu na mało liczne grupy pacjentów leczone tą metodą, jak również na fakt, że część doniesień pochodzi z okresu, kiedy skuteczność stosowanego leczenia hematologicznego była niższa.

Ograniczenia związane $z$ zastosowaniem wspomagania krążenia u pacjentów $z$ amyloidozą $\mathrm{AL}$ wynikają $z$ konieczności wspomagania głównie prawej komory i niemożności adekwatnego leczenia przeciwkrzepliwego w związku ze zwiększonym ryzykiem krwawienia. Ponadto często obserwowany w amyloidozie istotnie zmniejszony wymiar końcowo-rozkurczowy lewej komory jest niekorzystnym czynnikiem rokowniczym u chorych leczonych wspomaganiem lewej komory [92].

Częściej kandydatem do przeszczepienia serca może być pacjent $z$ amyloidozą ATTR. Choć u części pacjentów $z$ amyloidozą ATTR uwarunkowaną genetycznie rozważa się również przeszczep dwunarządowy - serca i wątroby. W ten sposób jednoczasowo $z$ leczeniem HF usuwa się narząd, który w głównej mierze odpowiada za produkcję zmutowanej TTR. Wykazano, że systemy wspomagania lewej komory mogą być wykorzystywane jako leczenie pomostowe u chorych na amyloidozę ATTR oczekujących na przeszczepienie serca, jednak należy się liczyć ze zwiększonym ryzykiem powikłań krwotocznych w tej grupie [93].

\section{Sytuacje szczególne}

Poniżej krótko opisano istotne problemy, $z$ którymi musi się zmierzyć kardiolog opiekujący się chorym na amyloidozę AL $z$ zajęciem serca.

\section{Zaawansowana niewydolność serca}

U pacjentów, u których amyloidozę rozpoznał kardiolog, postać choroby jest już zazwyczaj zaawansowana. Nasilona $\mathrm{HF}$ z jednej strony wymaga pilnej diagnostyki i jeśli stan ogólny pacjenta pozwala jeszcze na leczenie hematologiczne szybkiego skierowania pod opiekę hematologa, a $z$ drugiej strony — ostrożnego leczenia kardiologicznego. Leczenie diuretyczne polega na zręcznym balansowaniu między podawaniem adekwatnych dawek leków moczopędnych a kontrolowaniem, aby nie doszło do nadmiernego obniżenia obciążenia wstępnego. Konieczne są ścisłe monitorowanie stanu ogólnego, bilansu płynów, parametrów życiowych i biochemicznych pacjenta oraz częsta modyfikacja dawek leków. Zwiększona wrażliwość chorych na amyloidozę AL na toksyczne działanie leków nakazuje dużą rozwagę $\mathrm{w}$ doborze farmakoterapii.

\section{Nawracające bóle w klatce piersiowej}

Wysiłkowe bóle w klatce piersiowej lub nadbrzuszu mogą wynikać $z$ niewystarczającego rzutu serca, zmniejszenia światła małych naczyń przez złogi amyloidu w obrębie ściany naczynia [94], ale także - jak wykazano w ostatnim czasie $z$ upośledzonej funkcji mikrokrążenia wieńcowego w związku z obecnością FLC. Autorzy niniejszej pracy sugerują, aby w ramach diagnostyki bólów w klatce piersiowej u pacjentów $z$ amyloidozą nieobciążonych istotnymi czynnikami ryzyka choroby wieńcowej i z zachowaną frakcją wyrzutową lewej komory wykonać zamiast koronarografii tomografię komputerową tętnic wieńcowych $\mathrm{w}$ doświadczonym ośrodku. Warto mieć świadomość, że obniżenie stężenia FLC za pomocą leczenia cytoredukcyjnego może skutkować istotnym zmniejszeniem się bólów wysiłkowych.

\section{Kardiowersja elektryczna migotania przedsionków}

Nie ma odrębnych zaleceń dla chorych na amyloidozę AL dotyczących leczenia wspólistniejącego $\mathrm{u}$ nich AF za pomocą kardiowersji elektrycznej. Podobnie jak u innych pacjentów, kardiowersja jest wskazana w sytuacji, gdy nagłe wystąpienie AF powoduje niestabilność hemodynamiczną [95]. Jednak $\mathrm{u}$ chorych na amyloidozę AL, ze względu na zwiększone ryzyko incydentów zatorowych, kardiowersja elektryczna każdorazowo powinna być poprzedzona wykonaniem echokardiografii przezprzełykowej (TEE, transesophageal echocardiography) w celu wykluczenia obecności skrzeplin w jamach serca. W przypadku przetrwałego AF skuteczność kardiowersji elektrycznej może być mniejsza niż $u$ pacjentów $z$ innymi chorobami serca. Jednocześnie, jeśli po skutecznej kardiowersji wystąpi bradykardia, to należy liczyć się z możliwym przejściowym pogorszeniem się stanu ogólnego pacjenta.

\section{Nagła duszność \\ Chory na amyloidozę AL w pierwszej kolej- ności wymaga wykluczenia zatorowości płucnej; zaostrzenie lewokomorowej HF jest mniej praw- dopodobne.}




\section{Hiponatremia}

Zaawansowana HF, intensywne leczenie diuretyczne, jadłowstręt czy — w rzadkich przypadkach — nacieczenie kory nadnerczy złogami amyloidu mogą się przyczynić do hiponatremii. Zazwyczaj jest to łagodna hiponatremia przebiegająca $z$ hiperwolemią. Ograniczenie podaży płynów oraz zalecenie pacjentowi, aby postarał się przyjmować choć niewielkie ilości pokarmu, powinno być leczeniem $z$ wyboru. Należy pamiętać, $\dot{z}$ e przetaczanie pacjentowi $z$ amyloidozą AL soli stężonej nasili objawy zastoinowe.

\section{Hipotensja ortostatyczna}

Chorych na amyloidozę AL w żadnym wypadku nie powinno się leczyć podawaniem płynów dożylnie, gdyż nasili to trudne do leczenia przewodnienie. Postępowanie niefarmakologiczne, które może zmniejszyć objawy hipotensji, obejmuje: noszenie przez chorego pończoch uciskowych, powolną pionizację, unikanie długiego przebywania w pozycji stojącej, unikanie obfitych posiłków czy wykonywania wysiłków po posiłku, oddawanie moczu w pozycji siedzącej w przypadku mężczyzn. W razie nieskuteczności takiego postępowania należy rozważyć włączenie midodryny w stopniowo zwiększanej dawce 2,5-10 mg podawanej 3-krotnie w ciągu doby, zazwyczaj co około 4 godziny $[9,68$, 96]. Natomiast fludrokortyzonu nie można stosować u pacjentów $z$ amyloidozą AL ze względu na nasilanie przewodnienia.

\section{Podsumowanie}

Ponieważ amyloidoza serca jest najczęstszą przyczyną kardiomiopatii o fizjologii restrykcyjnej, usprawiedliwione wydaje się rozpoczęcie diagnostyki pacjenta $z$ zaburzeniami restrykcyjnymi od badań w kierunku amyloidozy. Rekomenduje się, aby u każdego chorego na HFpEF albo na HF o niejasnej przyczynie czy $z$ nietypowym przerostem mięśnia sercowego oznaczono stosunek FLC kappa i FLC lambda w surowicy.

Scyntygrafia umożliwia różnicowanie amyloidozy ATTR i amyloidozy AL, natomiast w przypadku amyloidozy ATTR pozwala wykryć chorobę na wczesnym etapie, kiedy nie stwierdza się jeszcze nieprawidłowości w innych badaniach obrazowych serca.

Zajęcie serca w przebiegu amyloidozy jest częste i niezależnie od typu amyloidozy znacząco pogarsza rokowanie.

Podejrzenie amyloidozy AL $z$ zajęciem serca wymaga szybkiej diagnostyki. Znaczące pogarsza- nie się stanu ogólnego pacjenta pozostającego bez leczenia hematologicznego może być widoczne w kolejnych tygodniach. Dlatego można zaryzykować twierdzenie, że rola kardiologa sprowadza się do zminimalizowania opóźnienia na drodze od wysunięcia podejrzenia amyloidozy AL serca, poprzez potwierdzenie choroby, do skierowania pacjenta na leczenie przyczynowe przez hematologa.

Istotnie poprawily się przeżycia pacjentów $z$ wcześnie rozpoznaną i leczoną według najnowszych standardów amyloidozą AL, dlatego tak duże znaczenie ma czujność kardiologów, by nie przeoczyć tej choroby.

\section{Piśmiennictwo}

1. Wechalekar A, Gillmore J, Hawkins P. Systemic amyloidosis. The Lancet. 2016; 387(10038): 2641-2654, doi: 10.1016/s01406736(15)01274-x.

2. Castaño A, Drachman BM, Judge D, et al. Natural history and therapy of TTR-cardiac amyloidosis: emerging disease-modifying therapies from organ transplantation to stabilizer and silencer drugs. Heart Fail Rev. 2015; 20(2): 163-178, doi: 10.1007/s10741014-9462-7, indexed in Pubmed: 25408161.

3. Milani P, Merlini G, Palladini G. Light chain amyloidosis. Mediterr J Hematol Infect Dis. 2018; 10: e2018022.

4. Dispenzieri A, Buadi F, Kumar SK, et al. Treatment of immunoglobulin light chain amyloidosis: Mayo Stratification of Myeloma and risk-adapted Therapy (mSMART) Consensus Statement. Mayo Clin Proc. 2015; 90(8): 1054-1081, doi: 10.1016/j.mayocp.2015.06.009, indexed in Pubmed: 26250727.

5. Szczygieł JA, Wieczorek PZ, Drozd-Sokołowska J, et al. Impaired right ventricular function as a predictor of early mortality in patients with light-chain cardiac amyloidosis assessed in a cardiology department. Pol Arch Intern Med. 2017; 127(12): 854-864, doi: 10.20452/pamw.4135, indexed in Pubmed: 29112180.

6. Muchtar E, Gertz MA, Kumar SK, et al. Improved outcomes for newly diagnosed AL amyloidosis between 2000 and 2014: cracking the glass ceiling of early death. Blood. 2017; 129(15): 2111-2119, doi: 10.1182/blood-2016-11-751628, indexed in Pubmed: 28126928.

7. Grogan M, Dispenzieri A. Natural history and therapy of AL cardiac amyloidosis. Heart Fail Rev. 2015; 20(2): 155-162, doi: 10.1007/s10741-014-9464-5, indexed in Pubmed: 25447844.

8. Lousada I, Comenzo RL, Landau H, et al. Light chain amyloidosis: patient experience survey from the Amyloidosis Research Consortium. Adv Ther. 2015; 32(10): 920-928, doi: 10.1007/s12325015-0250-0, indexed in Pubmed: 26498944.

9. Falk RH, Alexander KM, Liao R, et al. AL (Light-Chain) cardiac amyloidosis: a review of diagnosis and therapy. J Am Coll Cardiol. 2016; 68(12): 1323-1341, doi: 10.1016/j.jacc.2016.06.053, indexed in Pubmed: 27634125.

10. Migrino RQ, Truran S, Gutterman DD, et al. Human microvascular dysfunction and apoptotic injury induced by $\mathrm{AL}$ amyloidosis light chain proteins. Am J Physiol Heart Circ Physiol. 2011; 301(6): H2305-H2312, doi: 10.1152/ajpheart.00503.2011, indexed in Pubmed: 21963839.

11. Murtagh B, Hammill SC, Gertz MA, et al. Electrocardiographic findings in primary systemic amyloidosis and biopsy-proven 
cardiac involvement. Am J Cardiol. 2005; 95(4): 535-537, doi: 10.1016/j.amjcard.2004.10.028, indexed in Pubmed: 15695149.

12. Said SM, Grogg KL, Smyrk TC. Gastric amyloidosis: clinicopathological correlations in 79 cases from a single institution. Hum Pathol. 2015; 46(4): 491-498, doi: 10.1016/j.humpath.2014.12.009, indexed in Pubmed: 25649008.

13. Rosenbaum E, Marks D, Raza S. Diagnosis and management of neuropathies associated with plasma cell dyscrasias. Hematol Oncol. 2018; 36(1): 3-14, doi: 10.1002/hon.2417, indexed in Pubmed: 28397326.

14. Burroughs EI, Aronson AE, Duffy JR, et al. Speech disorders in systemic amyloidosis. Br J Disord Commun. 1991; 26(2): 201-206, indexed in Pubmed: 1777399.

15. Szczygieł JA, Michałek P, Drozd-Sokołowska J. Soluble suppression of tumorigenicity 2 (sST2) and growth differentiation factor 15 (GDF-15) help to identify patients with light-chain amyloidosis in a cardiology department — a single centre study. International Symposion on Amyloidosis 2018. Kumamoto, Japan 2018.

16. Falk RH. Diagnosis and management of the cardiac amyloidoses. Circulation. 2005; 112(13): 2047-2060, doi: 10.1161/CIRCULATIONAHA.104.489187, indexed in Pubmed: 16186440.

17. Berk JL, Keane J, Seldin DC, et al. Persistent pleural effusions in primary systemic amyloidosis: etiology and prognosis. Chest. 2003; 124(3): 969-977, indexed in Pubmed: 12970025.

18. Dmoszyńska A, Usnarska-Zubkiewicz L, Walewski J, et al. Zalecenia Polskiej Grupy Szpiczakowej dotyczące rozpoznawania i leczenia szpiczaka plazmocytowego oraz innych dyskrazji plazmocytowych na rok 2017. Acta Haematol Pol. 2017; 48(2): 55-103, doi: 10.1016/j.achaem.2017.05.003.

19. Grogan M, Dispenzieri A, Gertz MA. Light-chain cardiac amyloidosis: strategies to promote early diagnosis and cardiac response. Heart. 2017; 103(14): 1065-1072, doi: 10.1136/ /heartjnl-2016-310704, indexed in Pubmed: 28456755.

20. Carroll JD, Gaasch W, McAdam K. Amyloid cardiomyopathy: characterization by a distinctive voltage/mass relation. Am J Cardiol. 1982; 49(1): 9-13, doi: 10.1016/0002-9149(82)90270-3.

21. Das MK, Khan B, Jacob S, et al. Significance of a fragmented QRS complex versus a $\mathrm{Q}$ wave in patients with coronary artery disease. Circulation. 2006; 113(21): 2495-2501, doi: 10.1161/ /CIRCULATIONAHA.105.595892, indexed in Pubmed: 16717150.

22. Perlini S, Salinaro F, Cappelli F, et al. Prognostic value of fragmented QRS in cardiac AL amyloidosis. Int J Cardiol. 2013; 167(5): 2156-2161, doi: 10.1016/j.jijcard.2012.05.097, indexed in Pubmed: 22748496.

23. Gertz MA, Benson MD, Dyck PJ, et al. Diagnosis, prognosis, and therapy of transthyretin amyloidosis. J Am Coll Cardiol. 2015; 66(21): 2451-2466, doi: 10.1016/j.jacc.2015.09.075, indexed in Pubmed: 26610878.

24. Halatchev IG, Zheng J, Ou J. Wild-type transthyretin cardiac amyloidosis (ATTRwt-CA), previously known as senile cardiac amyloidosis: clinical presentation, diagnosis, management and emerging therapies. J Thorac Dis. 2018; 10(3): 2034-2045, doi: 10.21037/jtd.2018.03.134, indexed in Pubmed: 29707360.

25. Nagueh SF, Smiseth OA, Appleton CP, et al. Recommendations for the evaluation of left ventricular diastolic function by echocardiography: an update from the American Society of Echocardiography and the European Association of Cardiovascular Imaging. J Am Soc Echocardiogr. 2016; 29(4): 277-314, doi: 10.1016/j. echo.2016.01.011, indexed in Pubmed: 27037982.

26. Klein AL, Hatle LK, Taliercio CP, et al. Serial Doppler echocardiographic follow-up of left ventricular diastolic function in cardiac amyloidosis. J Am Coll Cardiol. 1990; 16(5): 1135-1141, indexed in Pubmed: 2229760.

27. Phelan D, Collier P, Thavendiranathan P, et al. Relative apical sparing of longitudinal strain using two-dimensional speckle-tracking echocardiography is both sensitive and specific for the diagnosis of cardiac amyloidosis. Heart. 2012; 98(19): 1442-1448, doi: 10.1136/heartjnl-2012-302353, indexed in Pubmed: 22865865.

28. Bodez D, Ternacle J, Guellich A, et al. Prognostic value of right ventricular systolic function in cardiac amyloidosis. Amyloid. 2016; 23(3): 158-167, doi: 10.1080/13506129.2016.1194264, indexed in Pubmed: 27348696.

29. Uzan C, Lairez O, Raud-Raynier P, et al. Right ventricular longitudinal strain: a tool for diagnosis and prognosis in light-chain amyloidosis. Amyloid. 2018; 25(1): 18-25, doi: 10.1080/13506129. 2017.1417121, indexed in Pubmed: 29260587.

30. Patel AR, Dubrey SW, Mendes LA, et al. Right ventricular dilation in primary amyloidosis: an independent predictor of survival. Am J Cardiol. 1997; 80(4): 486-492, indexed in Pubmed: 9285663.

31. Dubrey S, Pollak A, Skinner M, et al. Atrial thrombi occurring during sinus rhythm in cardiac amyloidosis: evidence for atrial electromechanical dissociation. Br Heart J. 1995; 74(5): 541-544, indexed in Pubmed: 8562243.

32. Lee GaY, Kim K, Choi JO, et al. Cardiac amyloidosis without increased left ventricular wall thickness. Mayo Clin Proc. 2014; 89(6): 781-789, doi: 10.1016/j.mayocp.2014.01.013, indexed in Pubmed: 24702732.

33. Philippakis AA, Falk RH. Cardiac amyloidosis mimicking hypertrophic cardiomyopathy with obstruction: treatment with disopyramide. Circulation. 2012; 125(14): 1821-1824, doi: 10.1161/ /CIRCULATIONAHA.111.064246, indexed in Pubmed: 22492950.

34. Vogelsberg H, Mahrholdt H, Deluigi CC, et al. Cardiovascular magnetic resonance in clinically suspected cardiac amyloidosis: noninvasive imaging compared to endomyocardial biopsy. J Am Coll Cardiol. 2008; 51(10): 1022-1030, doi: 10.1016/j. jacc.2007.10.049, indexed in Pubmed: 18325442.

35. Kwong RY, Heydari B, Abbasi S, et al. Characterization of cardiac amyloidosis by atrial late gadolinium enhancement using contrast-enhanced cardiac magnetic resonance imaging and correlation with left atrial conduit and contractile function. Am J Cardiol. 2015; 116(4): 622-629, doi: 10.1016/j.amjcard.2015.05.021, indexed in Pubmed: 26076990.

36. Banypersad SM, Fontana M, Maestrini V, et al. T1 mapping and survival in systemic light-chain amyloidosis. Eur Heart J. 2015; 36(4): 244-251, doi: 10.1093/eurheartj/ehu444, indexed in Pubmed: 25411195.

37. Fontana M, Pica S, Reant P, et al. Prognostic value of late gadolinium enhancement cardiovascular magnetic resonance in cardiac amyloidosis. Circulation. 2015; 132(16): 1570-1579, doi: 10.1161/ /CIRCULATIONAHA.115.016567, indexed in Pubmed: 26362631.

38. Bonnichsen CR, Glockner JF, Grogan M. Improvement in myocardial delayed enhancement after autologous stem cell transplant in a patient with light chain amyloidosis. Circ Heart Fail. 2012; 5(3): e55, doi: 10.1161/CIRCHEARTFAILURE.112.967935, indexed in Pubmed: 22589368.

39. Shi J, Guan J, Jiang B, et al. Amyloidogenic light chains induce cardiomyocyte contractile dysfunction and apoptosis via a noncanonical p38alpha MAPK pathway. Proc Natl Acad Sci USA. 2010; 107(9): 4188-4193, doi: 10.1073/pnas.0912263107, indexed in Pubmed: 20150510. 
40. Palladini G, Campana C, Klersy C, et al. Serum N-terminal pro-brain natriuretic peptide is a sensitive marker of myocardial dysfunction in AL amyloidosis. Circulation. 2003; 107(19): 2440-2445, doi: 10.1161/01.CIR.0000068314.02595.B2, indexed in Pubmed: 12719281.

41. Dispenzieri A, Gertz M, Kyle R, et al. Serum cardiac troponins and N-terminal pro-brain natriuretic peptide: a staging system for primary systemic amyloidosis. J Clin Oncol. 2004; 22(18): 3751-3757, doi: 10.1200/jco.2004.03.029.

42. Palladini G, Foli A, Milani P, et al. Best use of cardiac biomarkers in patients with $\mathrm{AL}$ amyloidosis and renal failure. Am J Hematol. 2012; 87(5): 465-471, doi: 10.1002/ajh.23141, indexed in Pubmed: 22389105.

43. Palladini G, Milani P, Merlini G. Novel strategies for the diagnosis and treatment of cardiac amyloidosis. Expert Rev Cardiovasc Ther. 2015; 13(11): 1195-1211, doi: 10.1586/14779072.2015.109 3936, indexed in Pubmed: 26496239.

44. Dispenzieri A, Gertz MA, Kyle RA, et al. Prognostication of survival using cardiac troponins and $\mathrm{N}$-terminal pro-brain natriuretic peptide in patients with primary systemic amyloidosis undergoing peripheral blood stem cell transplantation. Blood. 2004; 104(6): 1881-1887, doi: 10.1182/blood-2004-01-0390, indexed in Pubmed: 15044258.

45. Palladini G, Dispenzieri A, Gertz MA, et al. New criteria for response to treatment in immunoglobulin light chain amyloidosis based on free light chain measurement and cardiac biomarkers: impact on survival outcomes. J Clin Oncol. 2012; 30(36): 4541-4549, doi: 10.1200/JCO.2011.37.7614, indexed in Pubmed: 23091105.

46. Muchtar E, Dispenzieri A, Leung N, et al. Depth of organ response in AL amyloidosis is associated with improved survival: grading the organ response criteria. Leukemia. 2018 [Epub ahead of print], doi: 10.1038/s41375-018-0060-x, indexed in Pubmed: 29581546.

47. Dispenzieri A, Dingli D, Kumar SK, et al. Discordance between serum cardiac biomarker and immunoglobulin-free light-chain response in patients with immunoglobulin light-chain amyloidosis treated with immune modulatory drugs. Am J Hematol. 2010; 85(10): 757-759, doi: 10.1002/ajh.21822, indexed in Pubmed: 20872958.

48. Tapan U, Seldin DC, Finn KT, et al. Increases in B-type natriuretic peptide (BNP) during treatment with lenalidomide in $\mathrm{AL}$ amyloidosis. Blood. 2010; 116(23): 5071-5072, doi: 10.1182/ /blood-2010-09-305136, indexed in Pubmed: 21127185.

49. Dispenzieri A, Gertz MA, Saenger A, et al. Soluble suppression of tumorigenicity 2 (sST2), but not galactin-3, adds to prognostication in patients with systemic $\mathrm{AL}$ amyloidosis independent of NT-proBNP and troponin T. Am J Hematol. 2015; 90(6): 524-528, doi: 10.1002/ajh.24001, indexed in Pubmed: 25753178.

50. Kastritis E, Papassotiriou I. Growth differentiation factor-15 in patients with light chain (AL) amyloidosis has independent prognostic significance and adds prognostic information related to risk of early death and renal outcomes. Blood. 2014; 124: 306.

51. Szczygieł JA, Michałek P, Drozd-Sokołowska J et al. sST-2 i GDF-15 jako nowoczesne markery kardiologiczne w amyloidzie serca z łańcuchów lekkich. XXVII Zjazd Polskiego Towarzystwa Hematologów i Transfuzjologów. 21-23 września 2017 r. Warszawa, Polska.

52. Kastritis E, Papassotiriou I, Merlini G, et al. Growth differentiation factor-15 is a new biomarker for survival and renal outcomes in light chain amyloidosis. Blood. 2018; 131(14):
1568-1575, doi: 10.1182/blood-2017-12-819904, indexed in Pubmed: 29386197.

53. Katzmann JA, Abraham RS, Dispenzieri A, et al. Diagnostic performance of quantitative kappa and lambda free light chain assays in clinical practice. Clin Chem. 2005; 51(5): 878-881, doi: 10.1373/ /clinchem.2004.046870, indexed in Pubmed: 15774572.

54. Kumar S, Dispenzieri A, Lacy MQ, et al. Revised prognostic staging system for light chain amyloidosis incorporating cardiac biomarkers and serum free light chain measurements. J Clin Oncol. 2012; 30(9): 989-995, doi: 10.1200/JCO.2011.38.5724, indexed in Pubmed: 22331953.

55. Phull P, Sanchorawala V, Connors LH, et al. Monoclonal gammopathy of undetermined significance in systemic transthyretin amyloidosis (ATTR). Amyloid. 2018; 25(1): 62-67, doi: 10.1080/1 3506129.2018.1436048, indexed in Pubmed: 29424556.

56. Maleszewski JJ, Murray DL, Dispenzieri A, et al. Relationship between monoclonal gammopathy and cardiac amyloid type. Cardiovasc Pathol. 2013; 22(3): 189-194, doi: 10.1016/j.carpath.2012.09.001, indexed in Pubmed: 23102805.

57. Dorbala S, Vangala D, Bruyere J, et al. Coronary microvascular dysfunction is related to abnormalities in myocardial structure and function in cardiac amyloidosis. JACC Heart Fail. 2014; 2(4): 358-367, doi: 10.1016/j.jchf.2014.03.009, indexed in Pubmed: 25023822 .

58. Pulido V, Doros G, Berk JL, et al. The six-minute walk test in patients with AL amyloidosis: a single centre case series. Br J Haematol. 2017; 177(3): 388-394, doi: 10.1111/bjh.14586, indexed in Pubmed: 28340285.

59. Flatman K, Foard D, Pyart E, et al. Six-minute walk test (6MWT) in AL amyloidosis — baseline and 12-month follow-up after chemotherapy. Amyloid. 2017; 24(Suppl 1): 62-63, doi: 10.1080/135061 29.2017.1293516, indexed in Pubmed: 28434348.

60. Gertz MA. Immunoglobulin light chain amyloidosis: 2011 update on diagnosis, risk-stratification, and management. Am J Hematol. 2011; 86(2): 180-186, doi: 10.1002/ajh.21934, indexed in Pubmed: 21264900.

61. Maleszewski JJ. Cardiac amyloidosis: pathology, nomenclature, and typing. Cardiovasc Pathol. 2015; 24(6): 343-350, doi: 10.1016/j.carpath.2015.07.008, indexed in Pubmed: 26361138.

62. Cooper LT, Baughman KL, Feldman AM, et al. The role of endomyocardial biopsy in the management of cardiovascular disease: a scientific statement from the American Heart Association, the American College of Cardiology, and the European Society of Cardiology Endorsed by the Heart Failure Society of America and the Heart Failure Association of the European Society of Cardiology. Eur Heart J. 2007; 28(24): 3076-3093, doi: 10.1093/eurheartj/ /ehm456, indexed in Pubmed: 17959624.

63. Quarta CC, Gonzalez-Lopez E, Gilbertson JA, et al. Diagnostic sensitivity of abdominal fat aspiration in cardiac amyloidosis. Eur Heart J. 2017; 38(24): 1905-1908, doi: 10.1093/eurheartj/ehx047, indexed in Pubmed: 28605421.

64. Milani P, Merlini G, Palladini G. Novel therapies in light chain amyloidosis. Kidney Int Rep. 2018; 3(3): 530-541, doi: 10.1016/j. ekir.2017.11.017, indexed in Pubmed: 29854961.

65. Rapezzi C, Quarta CC, Guidalotti PL, et al. Usefulness and limitations of 99mTc-3,3-diphosphono-1,2-propanodicarboxylic acid scintigraphy in the aetiological diagnosis of amyloidotic cardiomyopathy. Eur J Nucl Med Mol Imaging. 2011; 38(3): 470-478, doi: 10.1007/s00259-010-1642-7, indexed in Pubmed: 21069320.

66. Gillmore JD, Maurer M, Falk R, et al. Non-biopsy diagnosis of cardiac transthyretin amyloidosis. Circulation. 2016; 133(24): 2404-2412, doi: 10.1161/circulationaha.116.021612. 
67. Gawor M, Sioma A, Mazurkiewicz $Ł$, et al. Genetic diagnosis in transthyretin cardiac amyloidosis — a single Polish centre experience. Eur J Heart Fail. 2018; 20(Suppl. S1): 331.

68. Wechalekar AD, Gillmore JD, Bird J, et al. BCSH Committee. Guidelines on the management of AL amyloidosis. Br J Haematol. 2015; 168(2): 186-206, doi: 10.1111/bjh.13155, indexed in Pubmed: 25303672.

69. Siddiqi OK, Ruberg FL. Cardiac amyloidosis: an update on pathophysiology, diagnosis, and treatment. Trends Cardiovasc Med. 2018; 28(1): 10-21, doi: 10.1016/j.tcm.2017.07.004, indexed in Pubmed: 28739313.

70. Muchtar E, Gertz MA, Kumar SK, et al. Digoxin use in systemic light-chain (AL) amyloidosis: contra-indicated or cautious use? Amyloid. 2018 [Epub ahead of print]: 1-7, doi: 10.1080/13506129. 2018.1449744, indexed in Pubmed: 29529877.

71. Muchtar E, Dean DS, Dispenzieri A, et al. Prevalence and predictors of thyroid functional abnormalities in newly diagnosed $\mathrm{AL}$ amyloidosis. J Intern Med. 2017; 281(6): 611-619, doi: 10.1111/ /joim.12617, indexed in Pubmed: 28439924.

72. Gertz MA, Falk RH, Skinner M, et al. Worsening of congestive heart failure in amyloid heart disease treated by calcium channel-blocking agents. Am J Cardiol. 1985; 55(13 Pt 1): 1645, indexed in Pubmed: 4003314.

73. Pollak A, Falk RH. Left ventricular systolic dysfunction precipitated by verapamil in cardiac amyloidosis. Chest. 1993; 104(2): 618-620, indexed in Pubmed: 8339658.

74. d'Humières T, Fard D, Damy T, et al. Outcome of patients with cardiac amyloidosis admitted to an intensive care unit for acute heart failure. Arch Cardiovasc Dis. 2018 [Epub ahead of print], doi: 10.1016/j.acvd.2018.03.004, indexed in Pubmed: 29709420.

75. Choufani EB, Sanchorawala V, Ernst T, et al. Acquired factor X deficiency in patients with amyloid light-chain amyloidosis: incidence, bleeding manifestations, and response to high-dose chemotherapy. Blood. 2001; 97(6): 1885-1887, indexed in Pubmed: 11238135.

76. Mumford AD, O’Donnell J, Gillmore JD, et al. Bleeding symptoms and coagulation abnormalities in 337 patients with AL-amyloidosis. Br J Haematol. 2000; 110(2): 454-460, indexed in Pubmed: 10971408.

77. McPherson RA, Onstad JW, Ugoretz RJ, et al. Coagulopathy in amyloidosis: combined deficiency of factors IX and X. Am J Hematol. 1977; 3: 225-235, indexed in Pubmed: 602938.

78. Bever KM, Masha LI, Sun F, et al. Risk factors for venous thromboembolism in immunoglobulin light chain amyloidosis. Haematologica. 2016; 101(1): 86-90, doi: 10.3324/haematol.2015.133900, indexed in Pubmed: 26452981.

79. Gamba G, Montani N, Anesi E, et al. Abnormalities in thrombin-antithrombin pathway in AL amyloidosis. Amyloid. 1999; 6(4): 273-277.

80. Park H, Kim JW, Youk J, et al. Serum free light chain difference and $\beta 2$-microglobulin levels are risk factors for thromboembolic events in patients with AL amyloidosis. Clin Lymphoma Myeloma Leuk. 2018; 18(6): 408-414, doi: 10.1016/j.clml.2018.03.005, indexed in Pubmed: 29625928.

81. Pereira NL, Grogan M, Dec GW. Spectrum of restrictive and infiltrative cardiomyopathies: part 1 of a 2-part series. J Am Coll Cardiol. 2018; 71(10): 1130-1148, doi: 10.1016/j.jacc.2018.01.016, indexed in Pubmed: 29519355.

82. Bhogal S, Ladia V, Sitwala P, et al. Cardiac amyloidosis: an updated review with emphasis on diagnosis and future directions.
Curr Probl Cardiol. 2018; 43(1): 10-34, doi: 10.1016/j.cpcardiol. 2017.04.003, indexed in Pubmed: 29173805.

83. Ward JE, Ren R, Toraldo G, et al. Doxycycline reduces fibril formation in a transgenic mouse model of AL amyloidosis. Blood. 2011; 118(25): 6610-6617, doi: 10.1182/blood-2011-04-351643, indexed in Pubmed: 21998211.

84. Kumar SK, Dispenzieri A, Lacy MQ, et al. Doxycycline used as post-transplant antibacterial prophylaxis improves survival in patients with light chain amyloidosis undergoing autologous stem cell transplantation. Blood. 2012; 120: 3138.

85. Wechalekar AD, Whelan C. Encouraging impact of doxycycline on early mortality in cardiac light chain (AL) amyloidosis. Blood Cancer J. 2017; 7(3): e546, doi: 10.1038/bcj.2017.26, indexed in Pubmed: 28338670.

86. Obici L, Cortese A, Lozza A, et al. Doxycycline plus tauroursodeoxycholic acid for transthyretin amyloidosis: a phase II study. Amyloid. 2012; 19(Suppl 1): 34-36, doi: 10.3109/13506129.2012. 678508, indexed in Pubmed: 22551192.

87. Lin G, Dispenzieri A, Kyle R, et al. Implantable cardioverter defibrillators in patients with cardiac amyloidosis. J Cardiovasc Electrophysiol. 2013; 24(7): 793-798, doi: 10.1111/jce.12123, indexed in Pubmed: 23489983.

88. Sayed RH, Rogers D, Khan F, et al. A study of implanted cardiac rhythm recorders in advanced cardiac AL amyloidosis. Eur Heart J. 2015; 36(18): 1098-1105, doi: 10.1093/eurheartj/ehu506, indexed in Pubmed: 25549725.

89. Barbhaiya CR, Kumar S, Baldinger SH, et al. Electrophysiologic assessment of conduction abnormalities and atrial arrhythmias associated with amyloid cardiomyopathy. Heart Rhythm. 2016; 13(2): 383-390, doi: 10.1016/j.hrthm.2015.09.016, indexed in Pubmed: 26400855.

90. Grogan M, Gertz M, McCurdy A, et al. Long term outcomes of cardiac transplant for immunoglobulin light chain amyloidosis: the Mayo Clinic experience. World J Transplant. 2016; 6(2): 380-388, doi: 10.5500/wjt.v6.i2.380, indexed in Pubmed: 27358783.

91. Palladini G, Merlini G. What is new in diagnosis and management of light chain amyloidosis? Blood. 2016; 128(2): 159-168, doi: 10.1182/blood-2016-01-629790.

92. Patel SR, Saeed O, Naftel D, et al. Outcomes of restrictive and hypertrophic cardiomyopathies after LVAD: an INTERMACS analysis. J Card Fail. 2017; 23(12): 859-867, doi: 10.1016/j.cardfail.2017.09.011, indexed in Pubmed: 28970073.

93. Swiecicki PL, Edwards BS, Kushwaha SS, et al. Left ventricular device implantation for advanced cardiac amyloidosis. J Heart Lung Transplant. 2013; 32(5): 563-568, doi: 10.1016/j. healun.2013.01.987, indexed in Pubmed: 23474361.

94. Mueller PS, Edwards WD, Gertz MA. Symptomatic ischemic heart disease resulting from obstructive intramural coronary amyloidosis. Am J Med. 2000; 109(3): 181-188, indexed in Pubmed: 10974179.

95. Kirchhof P, Benussi S, Kotecha D, et al. ESC Scientific Document Group. 2016 ESC Guidelines for the management of atrial fibrillation developed in collaboration with EACTS. Eur Heart J. 2016; 37(38): 2893-2962, doi: 10.1093/eurheartj/ehw210, indexed in Pubmed: 27567408.

96. Brignole M, Moya A, de Lange FJ, et al. ESC Scientific Document Group . 2018 ESC Guidelines for the diagnosis and management of syncope. Eur Heart J. 2018; 39(21): 1883-1948, doi: 10.1093/ /eurheartj/ehy037, indexed in Pubmed: 29562304. 